\title{
Article \\ Scaffolds for Cultured Meat on the Basis of Polysaccharide Hydrogels Enriched with Plant-Based Proteins
}

\author{
Jannis O. Wollschlaeger ${ }^{1}$, Robin Maatz ${ }^{2}$, Franziska B. Albrecht ${ }^{1}$, Annemarie Klatt ${ }^{1}$, Simon Heine ${ }^{1}$ (D), \\ Andreas Blaeser ${ }^{2,3}$ and Petra J. Kluger $4, *$ (D) \\ 1 Reutlingen Research Institute, Reutlingen University, 72762 Reutlingen, Germany; \\ jannis.wollschlaeger@reutlingen-university.de (J.O.W.); franziska.albrecht@reutlingen-university.de (F.B.A.); \\ annemarie.klatt@reutlingen-university.de (A.K.); simon.heine@reutlingen-university.de (S.H.) \\ 2 Institute for BioMedical Printing Technology, Technical University of Darmstadt, 64289 Darmstadt, Germany; \\ maatz@idd.tu-darmstadt.de (R.M.); blaeser@idd.tu-darmstadt.de (A.B.) \\ 3 Centre for Synthetic Biology, Technical University of Darmstadt, 64289 Darmstadt, Germany \\ 4 School of Applied Chemistry, Reutlingen University, 72762 Reutlingen, Germany \\ * Correspondence: petra.kluger@reutlingen-university.de
}

Citation: Wollschlaeger, J.O.; Maatz, R.; Albrecht, F.B.; Klatt, A.; Heine, S.; Blaeser, A.; Kluger, P.J. Scaffolds for Cultured Meat on the Basis of

Polysaccharide Hydrogels Enriched with Plant-Based Proteins. Gels 2022, 8, 94. https://doi.org/10.3390/ gels8020094

Academic Editor: Ivan Donati

Received: 29 December 2021

Accepted: 1 February 2022

Published: 4 February 2022

Publisher's Note: MDPI stays neutral with regard to jurisdictional claims in published maps and institutional affiliations.

Copyright: (c) 2022 by the authors. Licensee MDPI, Basel, Switzerland. This article is an open access article distributed under the terms and conditions of the Creative Commons Attribution (CC BY) license (https:/ / creativecommons.org/licenses/by/ $4.0 /)$.

\begin{abstract}
The world population is growing and alternative ways of satisfying the increasing demand for meat are being explored, such as using animal cells for the fabrication of cultured meat. Edible biomaterials are required as supporting structures. Hence, we chose agarose, gellan and a xanthanlocust bean gum blend (XLB) as support materials with pea and soy protein additives and analyzed them regarding material properties and biocompatibility. We successfully built stable hydrogels containing up to $1 \%$ pea or soy protein. Higher amounts of protein resulted in poor handling properties and unstable gels. The gelation temperature range for agarose and gellan blends is between $23-30{ }^{\circ} \mathrm{C}$, but for $\mathrm{XLB}$ blends it is above $55{ }^{\circ} \mathrm{C}$. A change in viscosity and a decrease in the swelling behavior was observed in the polysaccharide-protein gels compared to the pure polysaccharide gels. None of the leachates of the investigated materials had cytotoxic effects on the myoblast cell line $\mathrm{C} 2 \mathrm{C} 12$. All polysaccharide-protein blends evaluated turned out as potential candidates for cultured meat. For cell-laden gels, the gellan blends were the most suitable in terms of processing and uniform distribution of cells, followed by agarose blends, whereas no stable cell-laden gels could be formed with XLB blends.
\end{abstract}

Keywords: agarose; gellan; xanthan-locust bean gum blend; cell-laden hydrogels; C2C12 immortalized myoblasts; biofabrication

\section{Introduction}

Global meat production is on the rise in an effort to satisfy the dramatically increased meat consumption of a growing world population [1]. As large-scale conventional animal agriculture struggles to keep up with the demand, the problems of this industry increase with its size. In recent years, about $73 \%$ of worldwide sold antimicrobials are used in animals raised for meat production, increasing the risk of creating antibiotic-resistant bacteria [2]. In addition, over $70 \%$ of new infectious diseases in people originate in animals [3]. Furthermore, conventional meat production has a massive negative impact on the environment, considering usage of resources (energy, land, water) and the associated environmental footprint (greenhouse gases, deforestation, biodiversity loss), while animal welfare is also declining [4]. Therefore, more sustainable, safe und animal-friendly alternatives are desperately needed.

Cultured meat or in vitro meat creates the opportunity to produce meat without the need for raising the whole animal $[5,6]$. The needed cells can be grown in vitro using stem cells, for example, isolated from a small biopsy of an animal. To create a product that is as close as possible to a conventional whole meat cut, not only cells will be needed but a 
supporting matrix $[7,8]$. In vivo cells grow and function in a 3D gel-like microenvironment with tissue specific mechanical and biochemical properties, the extracellular matrix (ECM). Scaffolding materials can help to mimic this surrounding to enable cells to grow in a more in vivo state by delivering crucial mechanical cues [9].

The scaffolding material should not only support the cells, but also help to create a product with the desired consistency and appearance. To reproduce all important features of conventional meat, the set of requirements for biomaterials used to produce cultured meat is highly specific. The material should be edible, sustainable, widely available, animalfree, non-toxic, cheap, processable and ideally have none or only a mild taste $[7,10,11]$. Furthermore, the material can also add nutritional value to the product and improve the mouthfeel and with this, also help to improve customer acceptance [12]. Different types of scaffolds are suitable for cultured meat production and scale-up. While microcarriers can be used to scale up the production of cell mass, fibrous scaffolds can help to induce muscle fiber alignment [10,13-15]. Porous scaffolds such as hydrogels could increase nutrient, oxygen and waste transport within constructs. In addition, hydrogels are able to mimic the structure of the ECM and can also be used as bioinks in bioprinting processes, making them ideal candidates for larger cultured meat products such as whole meat cuts $[8,10,16-21]$. However, out of the numerous different hydrogel materials and blends, only a few are edible, widely available and animal-free. Some of these edible, plant-based candidates have already been approved by food safety authorities and are used in the food industry. Within this subset, plant-based and microorganism-produced polysaccharides are groups of biomaterials that include a variety of promising candidates that are also quite well-studied for their cytocompatibility [22,23].

Agar/agarose, gellan gum (gellan) and xanthan-locust bean gum blend (XLB) are approved as food additives and have been successfully used in different studies to investigate the mouse myoblast cell line C2C12 [24-26]. Those polysaccharides can form stable, predominantly tasteless hydrogels with tunable properties, but they have hardly any nutritional value [27]. Not only can the nutrient content of the scaffold be increased with the addition of plant proteins, but it can enrich the whole meat product with an extended amino acid profile [28]. Soy protein, pea protein and wheat protein isolates are widely available, cheap and are already used in the food industry to produce vegan alternatives mimicking conventional meat products. While wheat protein could represent yet another interesting source of plant protein, the broad usage of wheat protein, however, is hampered by problems associated with allergies [29] and the exaggerated public perception of wheat protein intolerances [30]. Therefore, soy and pea protein isolates are promising candidates to enrich the formulation of cultured meat scaffolds.

In this study, we investigated the influence of pea and soy protein isolates on the stability and the rheological properties of hydrogels from agarose, gellan and XLB. Furthermore, we examined the cytotoxicity of these blends by testing leachates of the hydrogels on the myoblast model cell line $\mathrm{C} 2 \mathrm{C} 12$ and by encapsulating these cells into the hydrogels.

\section{Results and Discussion}

As mentioned earlier, cultured meat products are being developed to address the various environmental issues associated with conventional meat production. Therefore, all materials and processes involved in cultured meat production are required to have minimal emissions and to be energy efficient in order to fulfill the promises made by the cultured meat industry. While all of the biomaterials investigated in this study only have a minor environmental footprint, their potential to provide an eco-friendlier meat alternative also depends on the specific species of the conventional meat product to which they are compared to.

Furthermore, raw material availability must be ensured to be able to produce large quantities at low cost. The polysaccharides (agarose, gellan, xanthan and locust bean gum (LBG)) and protein isolates (pea and soy protein) used here, are already approved as food additives and have various applications in the food industry. The availability of 
the proteins is significantly higher compared to the polysaccharides. However, in contrast to the protein additives, to create these hydrogels, less than $1 \%$ of the basic components are required. The annual worldwide meat production exceeded 300 million tons in the year 2020 [30]. Already, 1-3 million tons of cell-free scaffolds for cultured meat can be manufactured with the current production capacities of the hydrogel precursors (Table 1 annual production of agarose, gellan, xanthan and LBG), using $1 \%$ gels. In addition, an increase in the production capacities would likely follow a growing demand.

Table 1. Food and environmental characteristics of the biomaterials agarose, gellan, xanthan, locust bean gum, soy and pea protein.

\begin{tabular}{|c|c|c|c|c|c|c|c|c|c|}
\hline & Biomaterial & Taste & $\begin{array}{c}\text { Maximum } \\
\text { Daily Intake }\end{array}$ & $\begin{array}{l}\text { Allergy } \\
\text { Risks }\end{array}$ & Source/Origin & $\begin{array}{l}\text { Regulations } \\
\text { as Food }\end{array}$ & $\begin{array}{l}\text { Usage in } \\
\text { Food } \\
\text { Industry }\end{array}$ & $\begin{array}{c}\text { Annual } \\
\text { Production }\end{array}$ & $\begin{array}{c}\text { Environmental } \\
\text { Impact }\end{array}$ \\
\hline \multirow{4}{*}{ Hydrogel } & Agarose/Agar & $\begin{array}{c}\text { Tasteless } \\
{[31]}\end{array}$ & $\begin{array}{c}64 \mathrm{mg} / \mathrm{kg} \\
\text { body weight } \\
\text { per day } \\
{[32]}\end{array}$ & $\begin{array}{c}\text { Very low } \\
\text { [32] }\end{array}$ & $\begin{array}{c}\text { Sea weed, } \\
\text { red algae } \\
{[23]}\end{array}$ & $\begin{array}{c}\text { Evaluated as } \\
\text { food additive } \\
\text { [32] }\end{array}$ & $\begin{array}{c}\text { Thickener, } \\
\text { stabiliser, } \\
\text { gelling agent } \\
\text { [31] }\end{array}$ & $\begin{array}{c}>20,000 \mathrm{t} \\
{[33]}\end{array}$ & $\begin{array}{l}\text { Low } \\
{[34]}\end{array}$ \\
\hline & Gellan & $\begin{array}{c}\text { Tasteless } \\
{[35]}\end{array}$ & $\begin{array}{c}200 \mathrm{mg} / \mathrm{kg} \\
\text { body weight } \\
\text { per day } \\
{[36]}\end{array}$ & $\begin{array}{l}\text { Very low } \\
\text { [36] }\end{array}$ & $\begin{array}{l}\text { Pseudomonas } \\
\text { bacteria } \\
{[37]}\end{array}$ & $\begin{array}{c}\text { Evaluated as } \\
\text { food additive } \\
\text { [36] }\end{array}$ & $\begin{array}{c}\text { Thickener, } \\
\text { gelling agent } \\
\text { and stabiliser } \\
{[31]}\end{array}$ & $\begin{array}{c}>10,000 \mathrm{t} \\
{[38]}\end{array}$ & $\begin{array}{l}\text { Low-medium } \\
\text { [39-41] }\end{array}$ \\
\hline & Xanthan & $\begin{array}{c}\text { Tasteless } \\
{[42]}\end{array}$ & $\begin{array}{c}214 \mathrm{mg} / \mathrm{kg} \\
\text { body weight } \\
\text { per day } \\
{[43]}\end{array}$ & $\begin{array}{c}\text { Very low } \\
\text { [43] }\end{array}$ & $\begin{array}{c}\text { Xanthomonas } \\
{[44]}\end{array}$ & $\begin{array}{c}\text { Evaluated as } \\
\text { food additive } \\
\text { [43] }\end{array}$ & $\begin{array}{l}\text { Thickener, } \\
\text { stabiliser, } \\
\text { emulsifier, } \\
\text { foaming } \\
\text { agent } \\
\text { [31] }\end{array}$ & $\begin{array}{c}>30,000 \mathrm{t} \\
{[45]}\end{array}$ & $\begin{array}{c}\text { Low-medium } \\
{[46,47]}\end{array}$ \\
\hline & $\begin{array}{l}\text { Locust } \\
\text { Bean gum }\end{array}$ & $\begin{array}{c}\text { Tasteless, } \\
\text { Risk of } \\
\text { leguminous } \\
\text { taste when } \\
\text { heated } \\
{[48,49]}\end{array}$ & $\begin{array}{c}500 \mathrm{mg} / \mathrm{kg} \\
\text { body weight } \\
\text { per day } \\
{[50]}\end{array}$ & $\begin{array}{c}\text { Very low } \\
\text { [50] }\end{array}$ & $\begin{array}{c}\text { Carob tree } \\
\text { seeds } \\
\text { [51] }\end{array}$ & $\begin{array}{c}\text { Evaluated as } \\
\text { food additive } \\
\text { [50] }\end{array}$ & $\begin{array}{c}\text { Thickener, } \\
\text { gelling agent } \\
{[31]}\end{array}$ & $\begin{array}{c}>10,000 \mathrm{t} \\
{[52]}\end{array}$ & $\begin{array}{l}\text { Low } \\
{[53,54]}\end{array}$ \\
\hline \multirow{2}{*}{ Additive } & Pea protein & $\begin{array}{c}\text { Untreated: } \\
\text { Bitter, beany, } \\
\text { green, } \\
\text { grassy, and } \\
\text { leafy } \\
{[55,56]}\end{array}$ & $\begin{array}{c}30 \mathrm{~g} \\
\text { per day } \\
{[57]}\end{array}$ & $\begin{array}{l}\text { Low } \\
{[58]}\end{array}$ & $\begin{array}{c}\text { Pea, } \\
\text { Pisum } \\
\text { sativum } \\
{[59]}\end{array}$ & $\begin{array}{c}\text { Evaluated as } \\
\text { food additive } \\
\text { [60] }\end{array}$ & $\begin{array}{c}\text { Emulsifier, } \\
\text { foaming } \\
\text { agent, gelling } \\
\text { agent } \\
\text { [56] }\end{array}$ & $\begin{array}{c}>200,000 \mathrm{t} \\
{[61]}\end{array}$ & $\begin{array}{l}\text { Medium } \\
\text { [62] }\end{array}$ \\
\hline & Soy protein & $\begin{array}{c}\text { Untreated: } \\
\text { Bitter, beany, } \\
\text { fatty, green } \\
{[55]}\end{array}$ & $\begin{array}{c}25-100 \mathrm{~g} \\
\text { per day } \\
{[63]}\end{array}$ & $\begin{array}{l}\text { Low } \\
{[64]}\end{array}$ & $\begin{array}{c}\text { Soybean, } \\
\text { Glycine max } \\
{[65]}\end{array}$ & $\begin{array}{c}\text { Evaluated as } \\
\text { food additive } \\
\text { [66] }\end{array}$ & $\begin{array}{c}\text { Emulsifier, } \\
\text { foaming } \\
\text { agent, gelling } \\
\text { agent, fat and } \\
\text { water } \\
\text { absorption } \\
\text { [67] }\end{array}$ & $\begin{array}{c}>1,000,000 \mathrm{t} \\
{[65]}\end{array}$ & $\begin{array}{l}\text { Low-medium } \\
{[62,68,69]}\end{array}$ \\
\hline
\end{tabular}

All relevant information about the requirements for biomaterials used as scaffolds in the cultured meat sector is summarized in Table 1.

To increase the nutritional value of the gels and to potentially improve biocompatibility, different protein concentrations of pea and soy protein were tested for stable gel formations. Subsequently, the preselected polysaccharide-protein gel combinations were tested for their material properties in the sol-gel state and gel state and for their biocompatibility by both indirect cytotoxicity testing and viability testing after direct cell-encapsulation (Figure 1).

\subsection{Characterization of Gel Properties}

First, the amount of protein that did not interfere with the preparation and formation of stable gels with agarose, gellan and XLB (gel concentrations: $1 \%$ agarose, $1 \%$ gellan or $0.5 \%$ XLB) was determined. For XLB, a lower concentration was used because at a higher concentration ( $2 \%$ stock solution), the XLB powder was difficult to dissolve, and the resulting solution was very viscous and also difficult to mix with protein solutions. An increase in viscosity at higher concentrations of XLB has been shown previously [70]. The gel stability was assessed visually. The polysaccharides gellan and xanthan-locust bean gum blend undergo various crosslinking mechanisms to form hydrogels from solutions. Cooling plays a role in all of them. Whereas with agarose, this mechanism of self-gelation 
is solely responsible for gel formation, gellan can additionally be crosslinked with ions including sodium, calcium, magnesium and hydrogen ions $[37,71]$. Ions are also present in the cell culture medium. Therefore, the gellan gels were additionally crosslinked with the medium to have the same conditions in the cell-free experiments as in the cell culture. In the case of XLB, cooperative interactions between specific segments of xanthan with specific regions of LBG lead to gel formation [72].

Biomaterial Evaluation for Cultured Meat

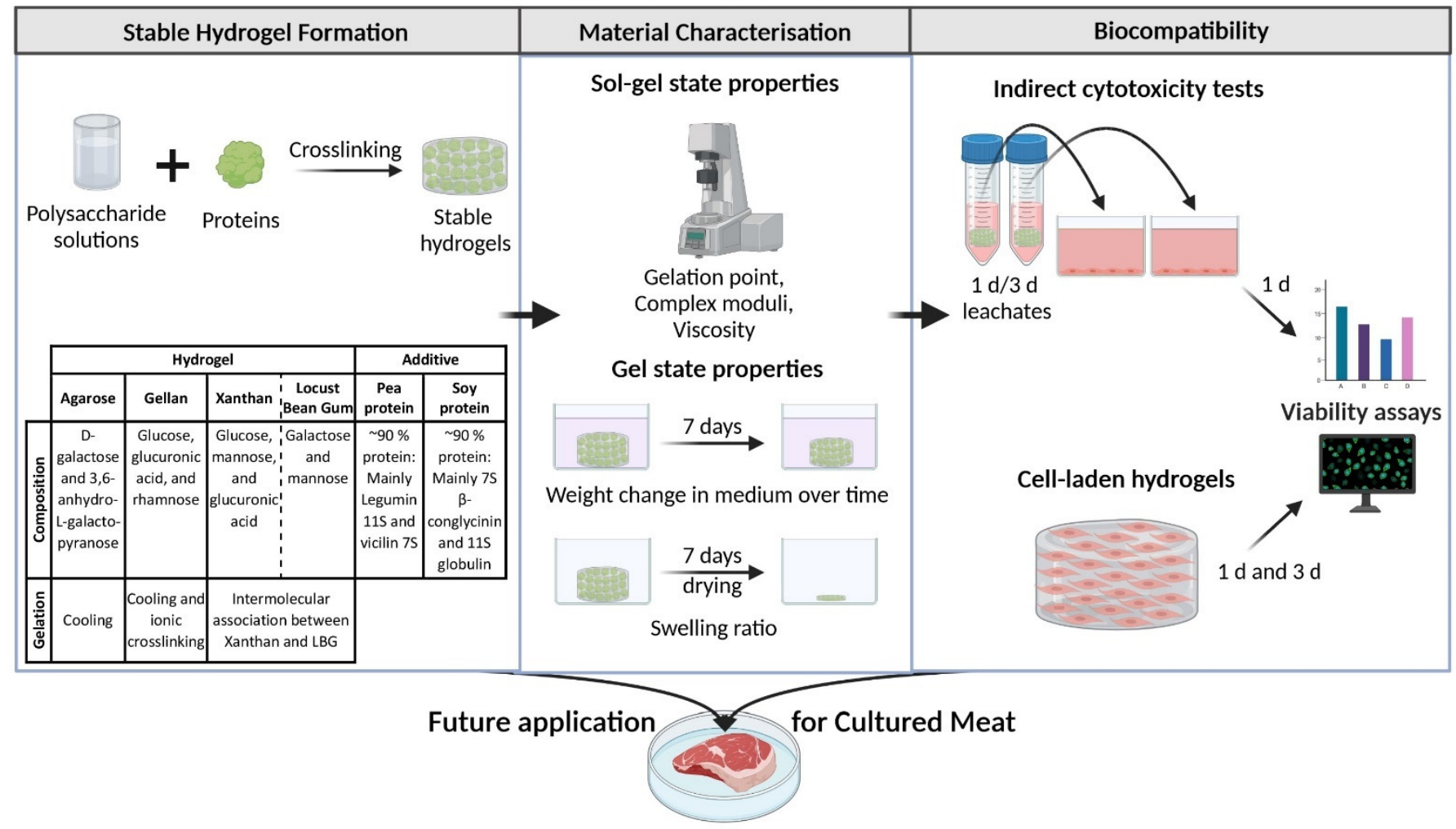

Figure 1. Schematic overview of the biomaterial evaluation in this study, starting with the investigation of stable gel formation of polysaccharide-protein blends and followed by the characterization of the material properties and biocompatibility to find suitable biomaterials for a future application in the cultured meat sector. This figure was created with BioRender.com, (accessed on 28 December 2021).

The addition of salt can actually lower the viscosity of XLB [73,74]. Hydrogels, composed solely of xanthan, usually require acidic compounds such as citric acid or adipic acidic for initiation of xanthan gelation [75]. Creating an acidic environment, however, can affect or even be harmful to cells when they are integrated into such hydrogels. XanthanLBG blends can therefore provide a more biocompatible alternative to xanthan alone.

In the literature, soy gels with up to $20 \%$ protein content have been produced [76]. However, soy protein isolates are not easily dissolved in water unless the $\mathrm{pH}$ of the solvent is increased or decreased from a pH of 7 [77]. Accordingly, stock solutions of $12 \%$ soy protein and $15 \%$ pea protein were prepared and mixed with the three polysaccharides to obtain protein blended gels containing up to $6 \%$ soy or $7.5 \%$ pea protein. The manufacturing of stable and uniform hydrogels was possible for agarose up to $2.5 \%$ protein supplementation. It was still possible to form gels with higher protein concentrations, but they were less dimensionally stable (Figure 2A). The increasing amount of protein may make it more difficult for the single agarose chains to agglomerate during the gelling process, leading to less stable gels. A similar effect was observed in another study when agarose was mixed with xanthan. The xanthan chains interfered with the agglomeration of the agarose chains by hindering them spatially [78]. Uniform gellan-protein blended hydrogels could only be casted using a maximum of $1 \%$ of protein. At higher concentrations, gellan began to 
gel more quickly during manufacturing, resulting in less uniform gels with rising protein concentration (Figure 2A).

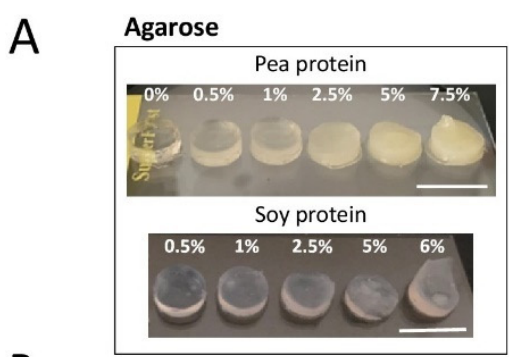

B

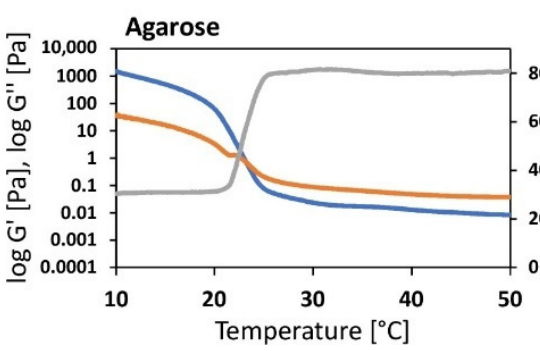

C

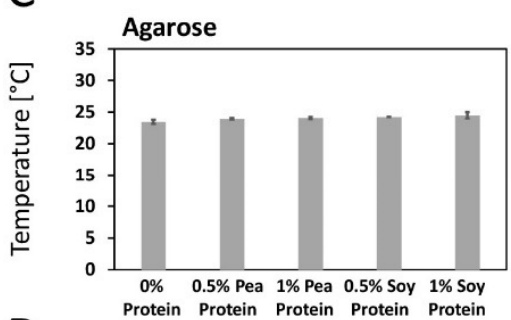

D

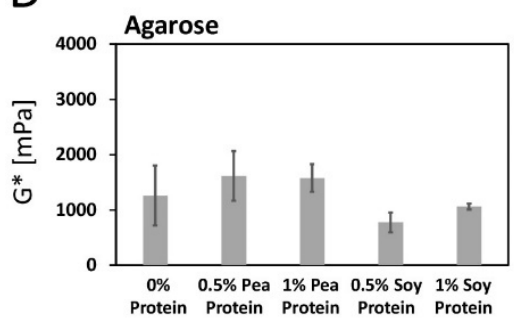

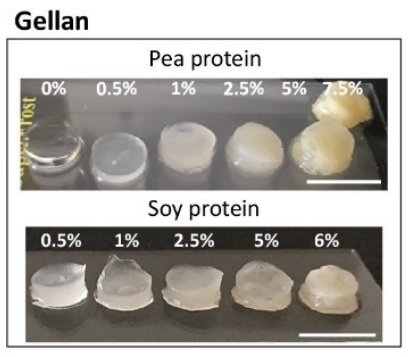
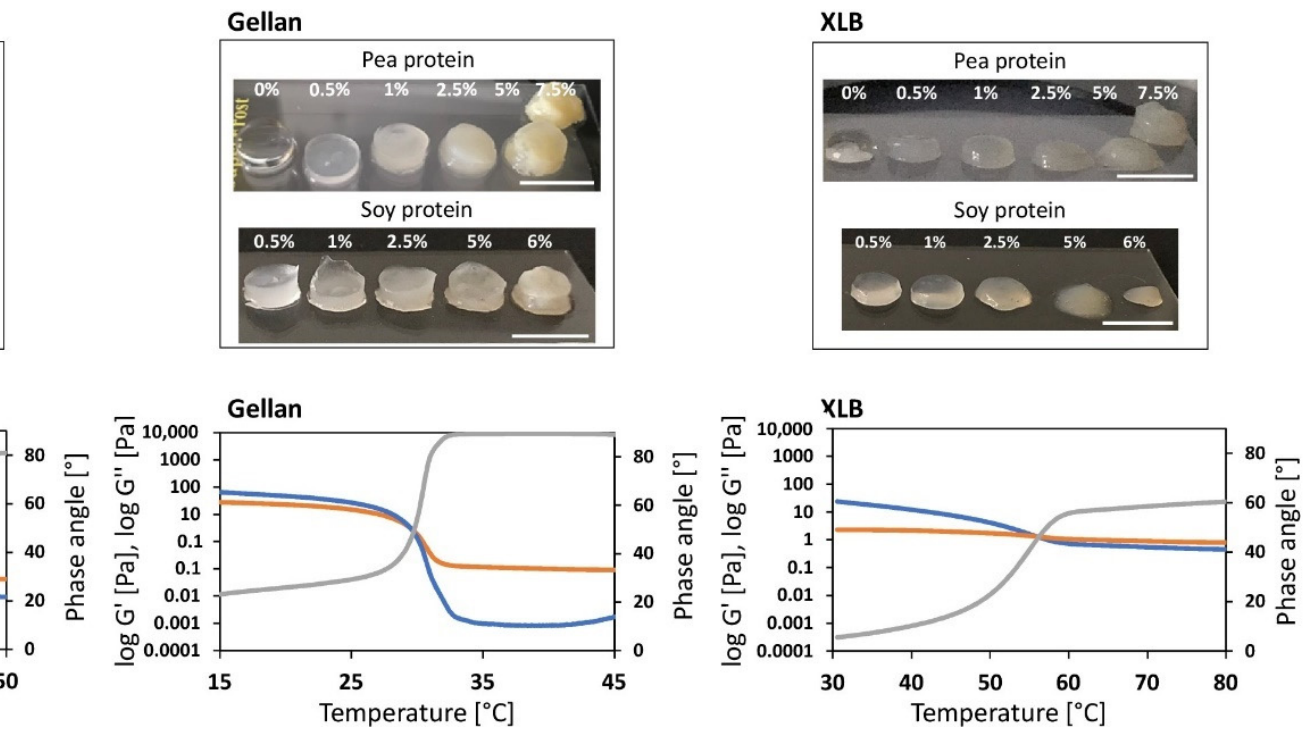

- Elastic modulus — Viscous modulus — Phase angle
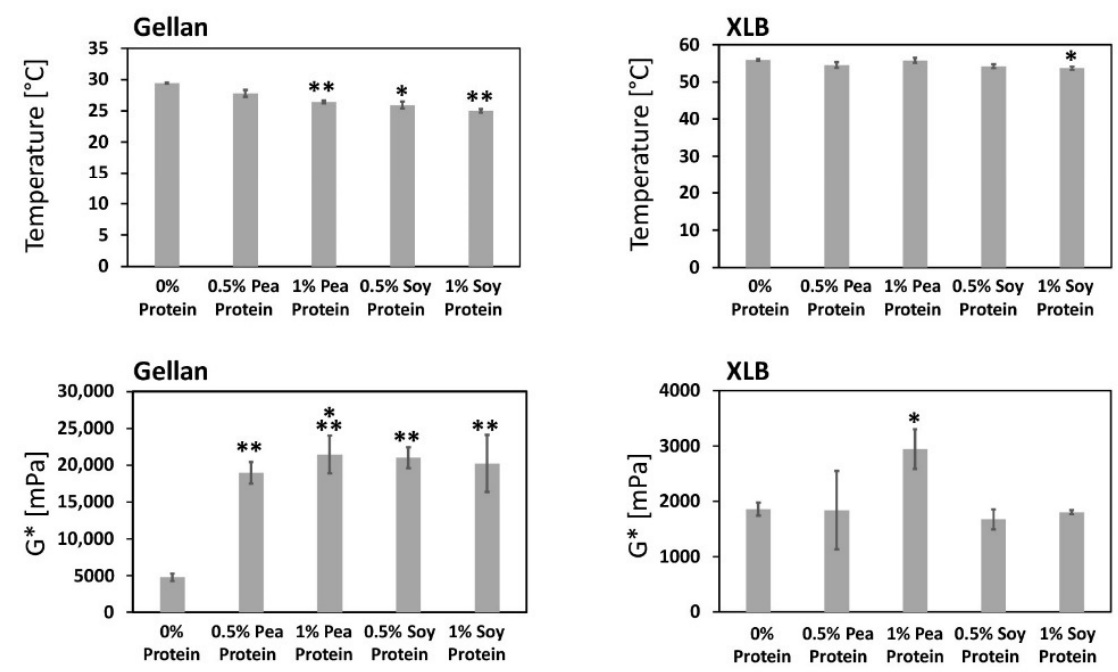

Figure 2. Sol-gel transition properties of agarose, gellan and XLB gels blended with pea or soy protein. (A) Gel formation of gels mixed with $0-7.5 \%$ pea protein and $0-6 \%$ soy protein, respectively. Scale bar: $10 \mathrm{~mm}$. (B) Rheological curves of protein-free agarose, gellan and XLB with elastic and viscous modulus and phase angle versus temperature $(1.0 \mathrm{~Hz}$ frequency and $1 \mathrm{~Pa}$ shear stress). (C) Temperature-dependent gelation points of polysaccharides blended with $0 \%, 0.5 \%$ and $1 \%$ pea or soy protein. ( $n=3$, two-sided t student test ${ }^{*} p<0.05$, ${ }^{* *} p<0.01$, respectively to $0 \%$ values). (D) Complex modulus at gelation points of gels blended with $0 \%, 0.5 \%$ and $1 \%$ pea or soy protein ( $n=3$, two-sided t student test ${ }^{*} p<0.05,{ }^{* *} p<0.01,{ }^{* * *} p<0.001$, respectively to $0 \%$ values). Error bars represent standard deviations.

An explanation for this may be the binding of positively charged amino acid side chains of the plant proteins to the negatively charged structures of gellan $[79,80]$. The ionic bonding of cations between the gellan chains could thereby be complicated, and thus would have an influence on gel stability. The observed faster gelation times at higher protein concentration may be explained by a faster cooling process. XLB gels were only stable up to $1 \%$ protein supplementation. With higher protein concentrations, mixing became more complicated and resulted in heterogeneous gels that fell apart (Figure 2A). Since the 
xanthan chains are also negatively charged, the positively charged protein side chains can also bind here and thus interfere with the binding to LBG chains [80].

Based on these results, preselected protein concentrations of $0.5 \%$ and $1 \%$ were used to perform all further tests.

\subsubsection{Impact of Protein Supplementation on Sol-Gel Transition}

The viscoelastic properties of the hydrogels and their blends were determined by oscillatory rheological measurements. First, the gelation point of the three polysaccharide-based hydrogels ranging from $23.5^{\circ} \mathrm{C}$ (agarose) to $29.4^{\circ} \mathrm{C}$ (gellan) and $55.9^{\circ} \mathrm{C}$ (XLB) were analyzed (Figure 2B,C). It is worth mentioning that the high-sol-gel transition temperature of XLB generally limits its applicability in the field of biofabrication, e.g., 3D-bioprinting [81], where cells are mixed with the hydrogel precursor prior to gelation [81]. Nevertheless, the material may still be used as a cellular building block to mechanically enhance the overall structure of biofabricated tissue constructs or as a niche that recruits surrounding cells during tissue maturation.

Next, the impact of protein supplementation was investigated. Differences in the gelation point can be observed for all investigated materials. However, both agarose and XLB protein supplementation only result in slight shifts in the sol-gel transition point in the order of $+/-4 \%$. Interestingly, a significant shift $(-5 \%$ to $-15 \%)$ of the gelling point towards lower temperatures can be observed in the investigated gellan samples. For instance, supplementation with $0.5 \%$ soy protein reduced the sol-gel transition to $25.9{ }^{\circ} \mathrm{C}$. A closer look at the rheological raw data (Figure S1) elucidates this effect. The shift of the gelation point, which is defined as the cross point of the measured elastic and viscous modulus, can be attributed to an overproportioned increase in the elastic modulus compared to its viscous counterpart at higher temperatures.

In general, temperature-dependent gelation of polysaccharides occurs due to the enhanced interactions of carbohydrate molecules with each other, at decreasing temperatures, resulting in crosslinking [79]. Proteins are known to form additional interactions with carbohydrate molecules [82-85]. It is conceivable that at the gelation temperature of gellan with $0 \%$ protein $\left(29.4^{\circ} \mathrm{C}\right)$, there is a lower proportion of cross-linked polysaccharide chains in the protein blends compared to gellan without protein, which means that no gelation point is yet visible in the blends. By lowering the temperature, the proportion of crosslinking increases further, and the gelation point is subsequently reached. Moreover, it is possible that the proteins cause a steric hindrance of the polysaccharide crosslinking, whereby the required proportion of crosslinks for the gelation point is only reached at lower temperatures. The data indicate that the elastic properties of gellan hydrogels are more strongly affected by protein supplementation than in the compared agarose and XLB gels. The results of the second experiment, which contrasts the elastic properties of the gels (Figure 2D), support this finding.

\subsubsection{Impact of Protein Supplementation on the Complex Shear Modulus}

To compare the mechanical properties of the hydrogels, their complex shear moduli were rheologically measured. Since the materials gel at different temperatures (as described previously), the complex shear modulus was assessed at the gelation point to enhance the comparability of the study. Pure agarose $(1260 \mathrm{mPa})$ and XLB $(1860 \mathrm{mPa})$ delivered comparable results. In contrast to these, the shear modulus of pure gellan at the gelling point was increased by more than the factor of two (4813 $\mathrm{mPa}$; Figure 2D). Interestingly, protein supplementation strongly affected the shear moduli of the studied materials. Shifts of $39 \%$ to $58 \%$ compared to the pure material were observed in agarose and XLB, yet no clear trend was visible. For instance, $1 \%$ pea protein supplementation increased the shear modulus of XLB to $2944 \mathrm{mPa}$, whereas $1 \%$ soy protein resulted in almost unaltered values $(1804 \mathrm{mPa})$ compared to the pure material.

Protein-polysaccharide interactions are associated with the complex formation of micro- and macro-structures, which are accompanied by a change in rheological properties. 
These depend on the protein and the polysaccharides that were mixed [82-85] and is driven mainly by forces of electrostatic interactions [86]. The structure of a protein is determined by its amino acid composition as well as its environment (e.g., $\mathrm{pH}$ and ionic strength) [87]. In addition, proteins show a different number of exposed charged amino acids [88]. Polysaccharides can also carry a different number of charged groups, which is associated with a different number of intra- and inter-molecular bonds and also depends on the environmental conditions. Furthermore, polysaccharides form different structures when they gel [89]. The significantly higher shear modulus in XLB 1\% pea $(2944 \mathrm{mPa})$ can be explained by the fact that XLB carries a higher number of negative charges than gellan and agarose.

In addition, under the present conditions, there may be a higher degree of intermolecular interactions with pea and thus the protein-polysaccharide interactions lead to higher strength. It can be seen that $1 \%$ soy $(1804 \mathrm{mPa})$ does not exhibit this behavior, which could be explained by a lower level of protein-polysaccharide interactions between soy and XLB, in comparison to pea and XLB. Nevertheless, the above-mentioned circumstances of protein-polysaccharide interactions make it difficult to compare the rheological behavior of polysaccharide-protein blends. Further, the results are in a protein concentration range for which a trend is not yet apparent, but which has been shown to be suitable, based on our previously acquired results (Figure 2A). Due to this, we consider it less relevant to choose a larger concentration range.

With an increase of approximately $400 \%$, the shear modulus of gellan exhibits the strongest alteration upon protein addition. For instance, supplementation of $1 \%$ pea protein yields a shear modulus of $21,451 \mathrm{mPa}$. Nevertheless, it should be regarded as an artifact of the shifted gelation point that was previously described (see Section 2.1.1). Correcting this effect by comparing the complex modules of protein-added gellan formulations at a similar temperature (e.g., at $27^{\circ} \mathrm{C}$ ), the values of the complex modules are converging $(0 \%=19,250 \mathrm{mPa}, 1 \%$ pea $=18,020 \mathrm{mPa}$ and $1 \%$ soy protein $=18,800 \mathrm{mPa})$. In summary, the comparison of different gel blends, that exhibit strongly varying sol-gel transition points, is challenging. In addition, it should be noted that the measured shear modulus at the gelling point only provides valuable information for the processability of the hydrogel formulation, e.g., using 3D-bioprinting, but does not directly represent the mechanical properties of the material.

\subsubsection{Impact of Protein Supplementation on the Homogeneity of the Polysaccharide Solution}

Agarose and gellan are transparent in the liquid state and become cloudy white after adding either soy or pea proteins. XLB is already slightly opaque without protein and becomes even cloudier after the addition of protein solutions (Figure 3A). All liquids showed a uniform coloration which indicated a homogeneous distribution of the proteins. This allowed for good further processing and continued uniform protein distribution in the solid hydrogels.

\subsubsection{Impact of Protein Supplementation on the Complex Shear Viscosity}

Assessment of the flow behavior of the studied hydrogel formulation is an important aspect when it comes to their automated processing in the future, e.g., using 3D bioprinting technology. This requires knowledge of the zero-shear viscosity as well as the shear thinning and shear thickening behavior. Therefore, the viscosity of the materials was measured over a wide shear rate range $\left(0.1-1000 \mathrm{~s}^{-1}\right)$ at temperatures above the gelation point. All gels exhibit non-newtonian (shear thinning) flow behavior and present a broad viscosity spectrum (Figure 3B). To quantitatively describe the rheological behavior of the gels, we determined the consistency factor $(\mathrm{K})$ and the flow exponent $(\mathrm{n})$ using the Ostwald-de Waele model, as previously described [90]. The consistency factor allows quantitative comparison of the different zero-shear viscosities of the materials, while the flow exponent indicates the degree of shear thinning. 
A

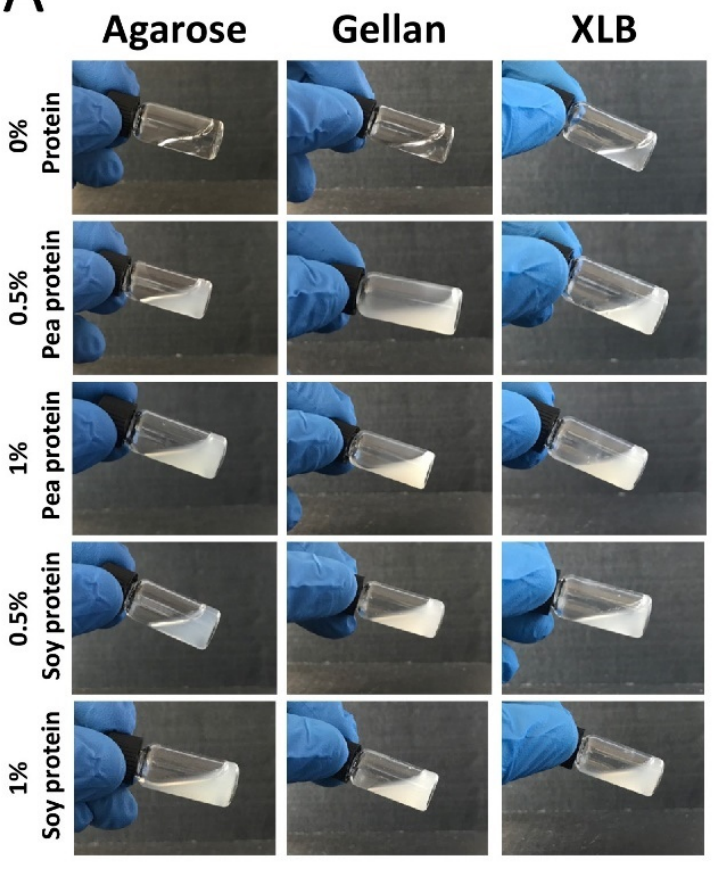

\begin{tabular}{|c|c|c|c|c|c|c|}
\cline { 2 - 7 } \multicolumn{1}{c|}{} & \multicolumn{2}{c|}{ Agarose } & \multicolumn{2}{c|}{ Gellan } & \multicolumn{2}{c|}{ XLB } \\
\cline { 2 - 7 } \multicolumn{1}{c|}{} & $\mathrm{n}$ & $\begin{array}{c}\mathrm{K} \\
{[\mathrm{mPa}]}\end{array}$ & $\mathrm{n}$ & $\begin{array}{c}\mathrm{K} \\
{[\mathrm{mPa}]}\end{array}$ & $\mathrm{n}$ & $\begin{array}{c}\mathrm{K} \\
{[\mathrm{mPa}]}\end{array}$ \\
\hline $\begin{array}{c}0 \% \\
\text { protein }\end{array}$ & 0.91 & 16.28 & 0.87 & 34.80 & 0.45 & 305.62 \\
\hline $\begin{array}{c}0.5 \% \\
\text { Pea protein }\end{array}$ & 0.94 & 12.06 & 0.87 & 46.06 & 0.46 & 385.90 \\
\hline $\begin{array}{c}1 \% \\
\text { Pea protein }\end{array}$ & 0.98 & 9.41 & 0.97 & 22.46 & 0.43 & 961.25 \\
\hline $\begin{array}{c}0.5 \% \\
\text { Soy protein }\end{array}$ & 0.98 & 7.10 & 0.95 & 27.19 & 0.48 & 254.76 \\
\hline $\begin{array}{c}1 \% \\
\text { Soy protein }\end{array}$ & 0.93 & 15.37 & 0.93 & 31.38 & 0.38 & 243.72 \\
\hline
\end{tabular}
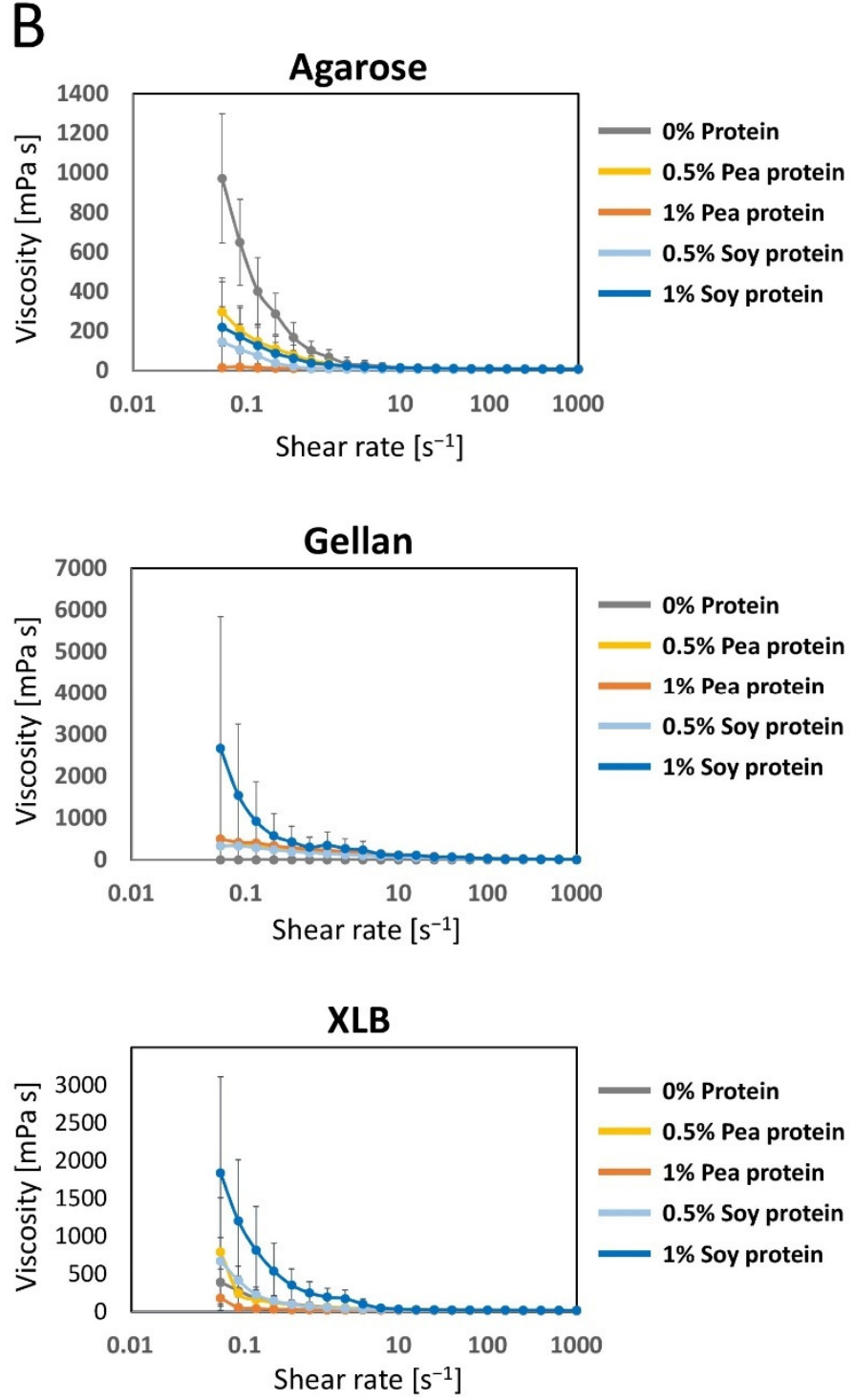

Figure 3. Sol state properties of agarose, gellan and XLB gels blended with $0 \%, 0.5 \%$ and $1 \%$ of pea or soy protein. (A) Liquid form of the different polysaccharide blends. (B) Viscosity over $\log _{10}$ (shear rate) curves of the different polysaccharide blends (agarose and gellan at $37^{\circ} \mathrm{C}$, and $\mathrm{XLB}$ at $65^{\circ} \mathrm{C}$ ). Error bars represent standard deviations. (C) Determined flow exponent (n)- and consistency factor (K)-value of the different gels.

The $\mathrm{n}$ and $\mathrm{K}$ values are concentration dependent, which has to be considered for the comparison of the hydrogels when it comes to their suitability in additive manufacturing [91]. Due to specific aspects that have emerged from our study (Sections 2.1 and 2.2), the concentration range for measuring shear viscosity was chosen and is thus limited to this area. Considering the flow exponent in the range of the chosen concentrations (Sections 2.1 and 2.2), the investigated materials extend over a broad zero-shear viscosity spectrum ranging from $16 \mathrm{mPas}$ (agarose) to over $300 \mathrm{mPas}$ (XLB). In general, these values represent a very good range for future post-processing using drop-on-demand 3D-bioprinting technology [90].

However, the materials strongly differ in their shear thinning behavior, as indicated by the strongly varying flow exponent ranging from 0.91 (agarose) to 0.87 (gellan) and 0.45 (XLB) (Figure 3C). In this regard, XLB may be of high interest for future processing using drop-on-demand 3D-bioprinting technology. Its strongly expressed shear thinning behavior reduces potential shear stress during printing, while its zero-shear viscosity is 
high enough to maintain structural integration and good shape fidelity of the printing structure. Nonetheless, from a rheological point of view, the other two gels, agarose and gellan, are also well suited for different biofabrication processes, as evidenced by their low zero-shear viscosity and their broad application spectra.

For all three materials, a slight change in the shear viscosity and shear thinning behavior is observed when pea and soy protein components are added (Figure 3C). However, no consistent trend can be seen in the influence of the protein addition on the consistency factor. Instead, the results indicate that the flow behavior of the gels due to the addition of the proteins varies depending on the matrix material. Therefore, we conclude that the added proteins interact with polysaccharide chains [82-85]. Adding proteins to a polysaccharide solution can generally increase the shear viscosity due to a higher stability of the protein-carbohydrate interactions. This would also lead to a higher zero-shear viscosity. For all three materials, a slight change in the shear viscosity and shear thinning behavior is observed when pea and soy protein components are added (Figure 3C). However, compared to the base hydrogel matrix, protein supplementation has only little effect on the rheological properties and only plays a minor role in altering the rheological process window.

Unexpectedly, high shear thinning is shown by XLB (0.45), which could be of great interest to the $3 \mathrm{D}$ bioprinting process. Especially there, the shear thinning behavior leads to a favorable property that has a positive effect on the printing process, which is characterized by the fact that the material is highly thinned during flow in the nozzle system and shows high dimensional stability and a low tendency to spread after flowing out [83-85].

\subsubsection{Impact of Protein Supplementation on Swelling Properties of the Hydrogels}

After characterization of the sol and sol-gel properties of the different hydrogels, the swelling ratios of the different hydrogels with or without protein were determined. In addition, the swelling behavior in cell culture medium was investigated by analyzing weight changes over seven days. For all three polysaccharides, the swelling ratios were significantly higher for the protein-free gels compared to the protein-supplemented gels. Within the protein-containing gels, at least for the soy gels, a decrease in the swelling ratio with increasing protein content was observed (not significantly for agarose; Figure 4A). This increase makes sense if the dry weight is considered, since the proteins increase the dry weight but not the water absorption capacity of the liquid in comparison to the respective polysaccharide. The swelling and release behavior of hydrogels plays an especially important role in drug delivery research. The swelling and release behavior of hydrogels depend, amongst others, on the hydrogel material, $\mathrm{pH}$ value, crosslinking process, temperature and the storage fluid [92].

The initial weights for the swelling behavior measurements of the $100 \mu \mathrm{L}$ gels were determined for all polysaccharides after incubating them $15 \mathrm{~min}$ in $1 \mathrm{~mL}$ media. This allowed for a better comparability between the additional ion crosslinked gellan and the other gels. The agarose gels showed no change in weight over the seven days in medium (Figure 4B). This behavior of agarose was shown before, even over a longer period [93]. Accordingly, neither the proteins nor agarose components were released into the medium to any extent. In contrast, gellan gels had a weight loss of around $10 \%$ within the first day, followed by another $5 \%$ weight loss up to day seven (Figure $4 \mathrm{~B}$ ). Since this decrease is similar in samples with or without protein supplementation, it is more likely to be due to the release or shrinking of gellan structures and less to protein release. The release of gellan chains was also previously described, with a weight loss between $5-15 \%$ over a period of 168 days [94]. The XLB gels showed the largest weight loss of around $30-40 \%$ on the first day. In addition, another decrease could still be observed over the next few days; however, not at such a high rate (Figure 4B). For the protein-free gels, weight reduction was not as strong with $64.3 \pm 8.7 \%$ of the original weight by day seven compared to the protein-containing gels ( $0.5 \%$ pea protein: $55.3 \pm 1.9 \%$; $1 \%$ pea protein: $56.3 \pm 2.2 \% ; 0.5 \%$ soy protein: $48.3 \pm 2.9 \% ; 1 \%$ soy protein: $46.8 \pm 1.2 \%)$. This may indicate that more proteins are released from XLB than polysaccharide chains. But further testing is required to confirm 
that there is a release of proteins from XLB gels. Subsequently, this can be addressed by conducting release experiments, in which the protein concentrations in the supernatant can be determined [95].

A
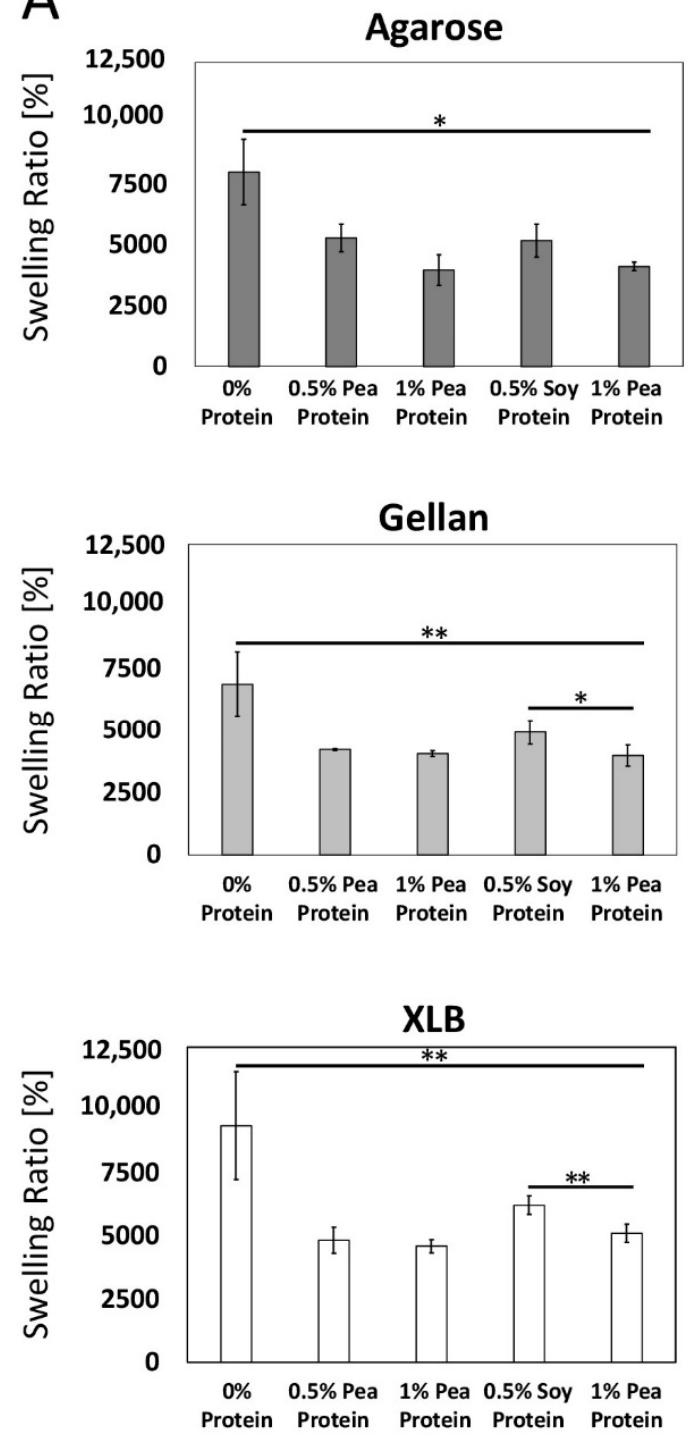

B

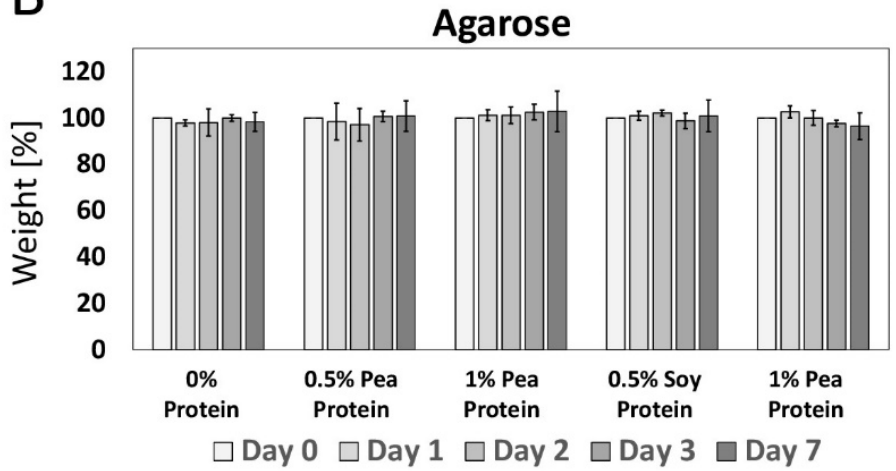

Gellan

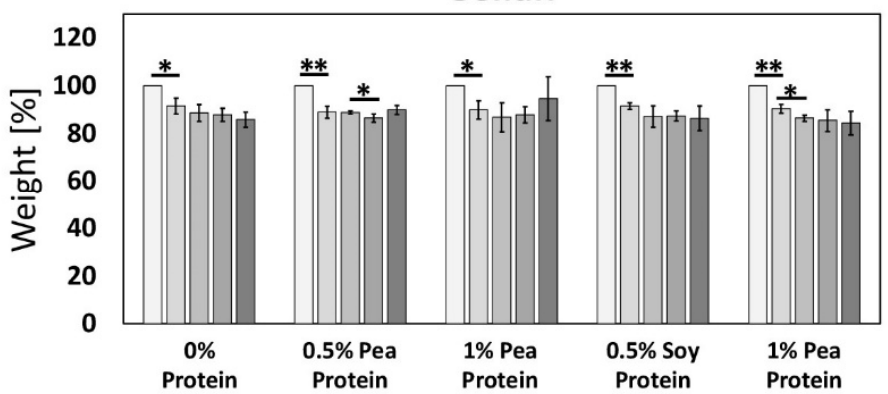

$\square$ Day $0 \square$ Day $1 \square$ Day $2 \square$ Day $3 \square$ Day 7

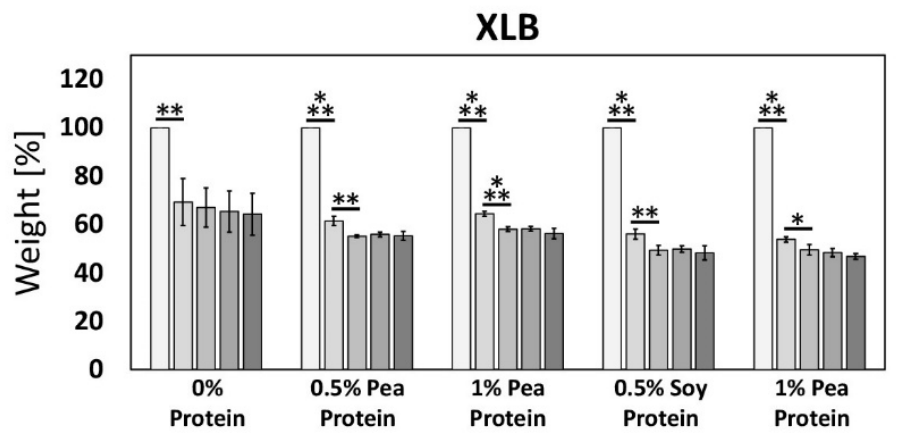

$\square$ Day $0 \square$ Day $1 \square$ Day $2 \square$ Day $3 \square$ Day 7

Figure 4. Swelling properties of agarose, gellan and XLB gels blended with $0 \%, 0.5 \%$ and $1 \%$ of pea or soy protein in gel state. (A) Swelling ratio of different gels $(n=4$, two-sided t student test * $p<0.05$, ** $p<0.01)$. (B) Weight change of different hydrogels over seven days in medium $(n=4$, two-sided $\mathrm{t}$ student test $\left.{ }^{*} p<0.05,{ }^{* *} p<0.01,{ }^{* * *} p<0.001\right)$. Error bars represent standard deviations.

\subsection{Biocompatibility of the Biomaterials}

2.2.1. Impact of Biomaterial Leachates on Cell Viability and Metabolic Activity

Day 1 and day 3 leachates of the different polysaccharide-protein hydrogel blends were tested for a one-day incubation period on C2C12 cells to observe their effects on cell viability and metabolic activity. The Live/Dead-stainings of the C2C12 cells show no differences for all samples compared to the medium control (Figure 5A), with only a few dead cells, whereas the TritonX-100 control shows only dead cells. Metabolic activity decreases in all leachates but decreases only significantly in leachates from XLB (day 1), XLB with $0.5 \%$ soy protein (day 1 and day 3 ), leachates from agarose (day 3 ), and leachates from gellan-protein blends (day 3), compared to medium controls (Figure 5B). However, the LDH release, which is released from cells only after cell death, is significantly lower for 
all samples compared to TritonX-100 controls and not significantly higher than the medium controls (Figure 5C).
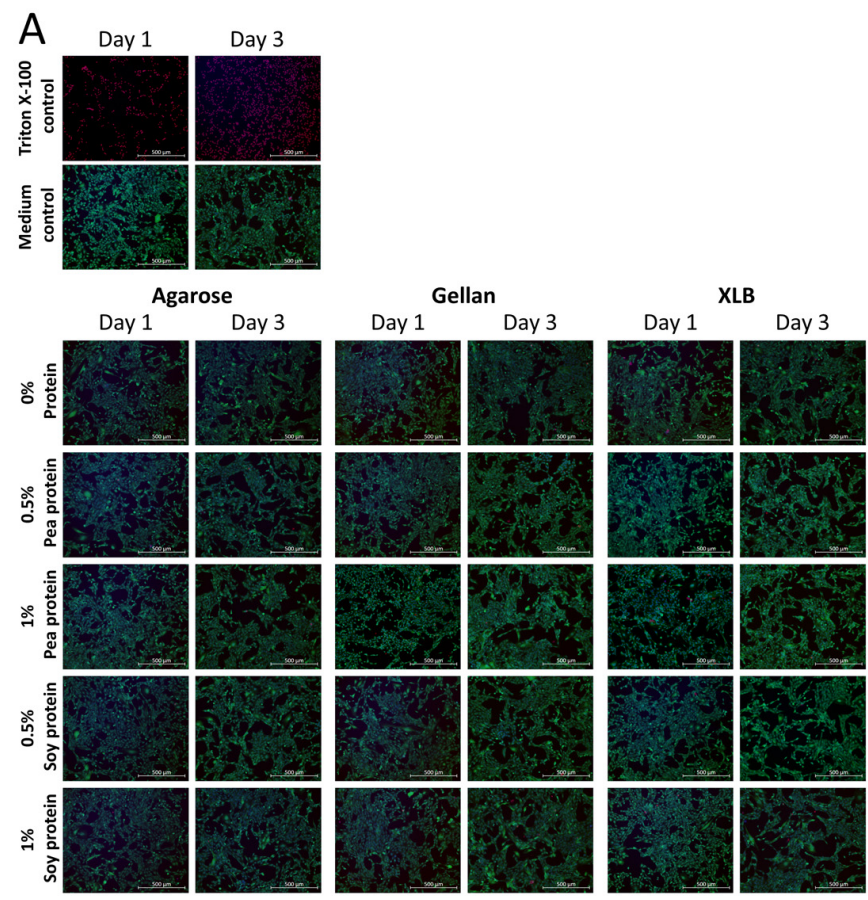

$\mathrm{B}$

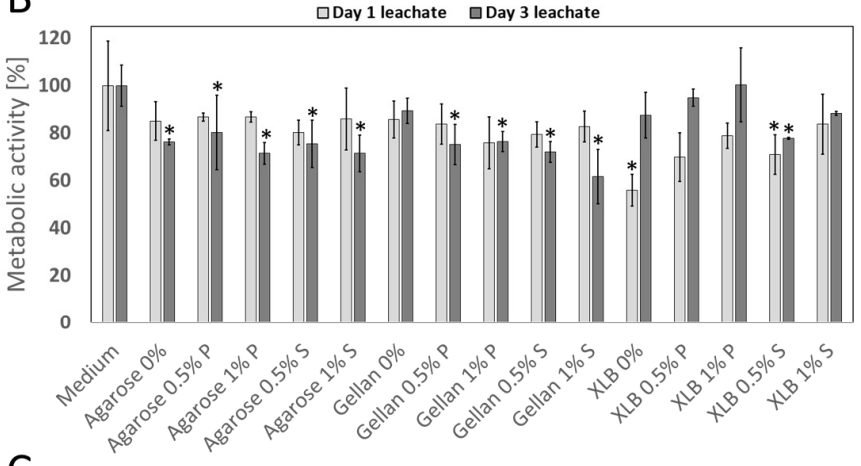

C

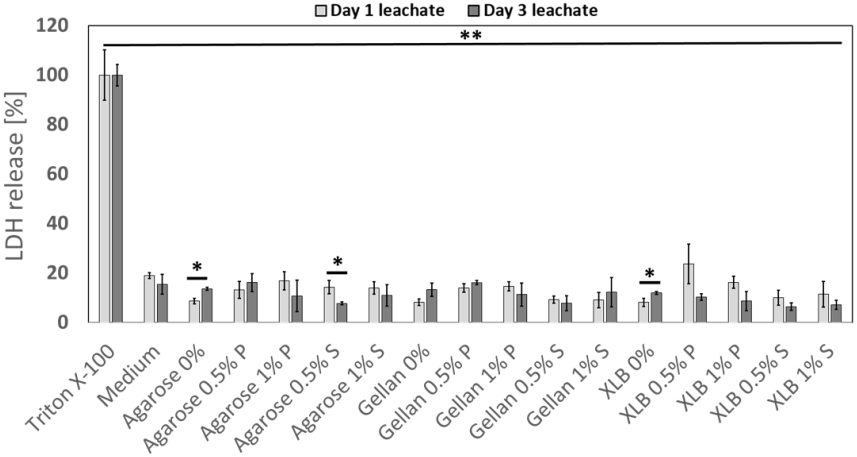

Figure 5. Biocompatibility testing using leachates (day 1 and day 3) of agarose, gellan and XLB gels blended with $0 \%, 0.5 \%$ and $1 \%$ of pea or soy protein with one day incubation on $\mathrm{C} 2 \mathrm{C} 12$ cells. (A) Live/Dead-staining of C2C12 cell. Green: viable cells; red: dead cells; blue: DNA/cell nuclei. Scale bar: $500 \mu \mathrm{m}$. (B) Metabolic activity of C2C12 after one day treatment with different leachates (day 1 and day 3 ) relative to medium control (medium treated same as leachates) ( $n=3$, two-sided $\mathrm{t}$ student test * $p<0.05$ respectively to medium control). (C) LDH release of C2C12 cells after one day treatment with different leachates (day 1 and day 3 ) relative to $0.1 \%$ TritonX-100 treated cells. $(n=3$, two-sided t student test ${ }^{*} p<0.05,{ }^{* *} p<0.01$ ). Error bars represent standard deviations. 
One possible explanation for the decreased metabolic activity, which occurs primarily in the day 3 leachates of agarose and gellan samples, can be a nonspecific binding of medium components to the polysaccharide structures or embedded proteins. In regenerative medicine, such mechanisms are mainly investigated for the immobilization and release of growth factors [96]. Since fetal calf serum (FCS) is used in the medium, which contains many different components such as growth factors, vitamins, peptides, proteins and more [97], it is difficult to identify specific components that may influence cellular activity. This effect may be less pronounced with XLB leachates, considering the results of the swelling test. They intrinsically lose weight over time and thus may bind fewer other substances.

However, this phenomenon may also be a problem in the subsequent application of cell-laden gels since the availability of the medium components for the cells may also be limited there. It would be interesting to see if this phenomenon also appears in FCS-free media, since all resources for cultured meat applications should be animal-free. FCS-free or serum-free media for mammalian cell culture and cultured meat research are currently extensively investigated, using, amongst others, recombinant growth factors and proteins [98-101]. Considering all the results of the biocompatibility tests (Live/Dead-staining, LDH assay, metabolic activity assay), however, there is no significant toxic influence of any of the used biomaterials or blends.

\subsubsection{Impact of Cell Encapsulation on Cell Viability}

To investigate the viability of the cells in direct contact with the biomaterials, in addition to indirect toxicity, cells were encapsulated directly into the different hydrogels. The liquid polysaccharide solutions were tempered to $37^{\circ} \mathrm{C}$ before mixing with the $\mathrm{C} 2 \mathrm{C} 12$ cells to avoid heat-induced cell death. At this temperature, however, the agarose gels were already too viscous and started gelling while mixing. Subsequently, the Live/Dead-staining showed a heterogeneous distribution of single and rounded cells and a formation of cell clusters within all agarose hydrogels (Figure 6). Most of the cells survived this procedure and were still alive after one day and three days in culture medium. It was easy to mix the liquid gellan-protein blends, as gellan remained liquid. In addition, the cell distribution within the gels was homogeneous and the cells showed a rounded morphology. The proportion of living cells was also high after one day and three days of culture (Figure 6).

In contrast, mixing of cells with the XLB-protein blends was challenging, due to the high gelation temperature of the gels of around $55^{\circ} \mathrm{C}$ (Figure 2C); the material already gelled before the mixing procedure with cells $\left(37^{\circ} \mathrm{C}\right)$ started. Pouring of gels within the preparation molds was still possible, but no stable gels were formed after the addition of medium (Figure S2). This caused the release of cells from the hydrogels. The released cells attached to each other and formed cell aggregates or were present as single cells (Figure 6). Since XLB is already in the gel state and the viscosity of agarose has already increased at $37^{\circ} \mathrm{C}$ (Figure $2 \mathrm{~B}, \mathrm{C}$ ), these are not optimal conditions for cellular encapsulation. Higher temperatures of the hydrogel solutions can solve this problem, but also increase cell death [102]. Since this is not desirable, other mixing techniques can also be helpful to improve cellular distribution within high viscous gels [103]. For example, in the mixing technique used in this study, gellan with and without protein is the best candidate to encapsulate cells and to build up a 3D cell environment.

No difference was observed between the protein blended and the pure polysaccharide gels. Thus, it cannot be shown that the proteins had a supporting effect on cell adhesion or cell growth within the three days. The more the natural environment of the cells, such as the ECM, is mimicked, the better the cells are supported by the biomaterials and show improved proliferation [104]. Agarose, gellan and XLB can give a supportive matrix environment for the cells, but do not support cell adhesion per se without being chemically or physically modified, e.g., crosslinking with peptides or RGD sequences [105-107]. The plant-based proteins can potentially support cell adhesion, which can also be improved by aforementioned modifications $[21,108,109]$. Despite all this, the spatial spread of the cells 
may also be limited by the surrounding matrix, even if the biomaterials can support cell growth as a substrate [108-111].

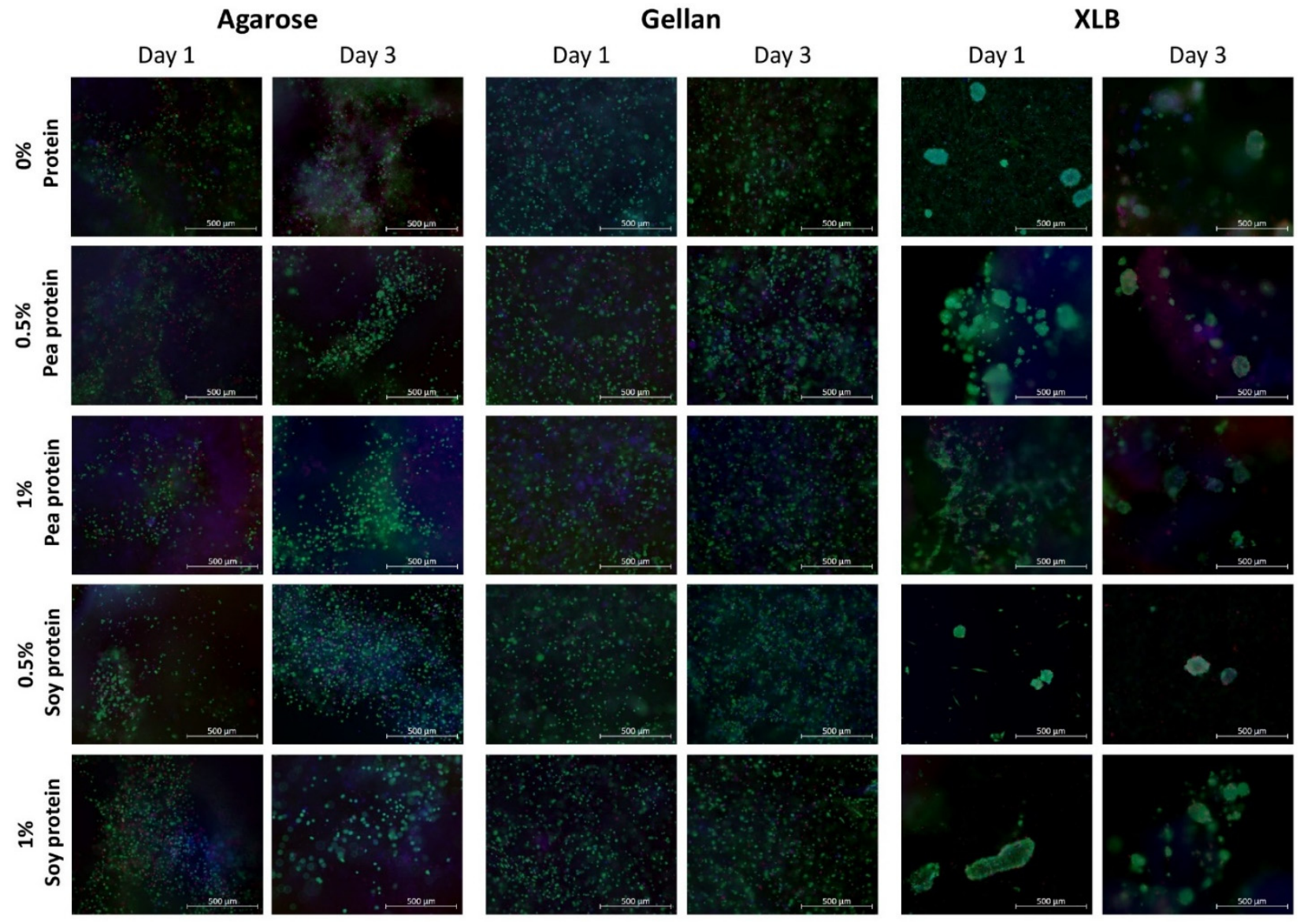

Figure 6. Live/Dead-staining of encapsulated C2C12 cells in agarose, gellan and XLB protein blended hydrogels $(0 \%, 0.5 \%$ and $1 \%$ pea or soy protein) after one day and three days of culture. Green: viable cells; red: dead cells; blue: DNA/cell nuclei. Scale bar: $500 \mu \mathrm{m}$.

To investigate the supportive properties of the biomaterials more in detail, the next step could be to perform specific stainings of proteins involved in cell adhesion, such as vinculin. Furthermore, a phalloidin-actin staining could provide a better insight into the predominant cell morphology [112]. In future studies, it would be interesting to determine if the cells stay viable in the gel during a longer cultivation period and if the protein supplements have an influence on cellular growth, cell morphology and differentiation.

\section{Conclusions}

Some main aspects can be derived from the results concerning the application of the polysaccharide-protein blended hydrogels for the cultured meat sector. First, it is possible to make protein blends (containing up to $1 \%$ of pea and soy protein) with all polysaccharides to increase the nutritional value without significantly affecting either the mechanical properties of the gels or cell viability within the gels. For agarose and gellan, even higher protein concentrations are possible, although with a decrease in hydrogel stability. These two candidates also show good gel stability over seven days in medium, whereas XLB significantly loses weight over time. Sustained hydrogel stability is useful to investigate whether the addition of protein promotes cell adhesion, cell growth and myogenic differentiation during prolonged cell culture. In addition, hydrogels must be non-toxic for muscle cells, which was confirmed for all the used biomaterials. Finally, there must be the possibility of encapsulating the cells homogeneously in the hydrogel solution while maintaining their viability. 
All requirements were most suitably fulfilled by gellan. However, for applications where an uneven cellular distribution is not an issue, cell-laden gels could also be prepared with agarose. For XLB, all cell-laden gels broke apart after rinsing with medium. The collective material properties are summarized and assessed in Table 2. Considering all these findings, gellan is best suited for cell encapsulation with an application in the cultured meat sector. Nevertheless, agarose performs well with optimization needed for cell-containing gel assembly. Only XLB showed some processing difficulties due to the comparatively high processing temperature. Due to its biocompatibility, it is still conceivable to find another use for cultured meat applications.

Table 2. Summarized results for different polysaccharides (agarose, gellan and xanthan-locust bean gum blend) with application relevant information: (+) very good properties, (+/o) good properties, $(+/-)$ acceptable properties, and (-) poor properties.

\begin{tabular}{|c|c|c|c|c|c|}
\hline Polysaccharide & $\begin{array}{l}\text { Gel Formation } \\
\text { with Protein }\end{array}$ & $\begin{array}{c}\text { Form Stability } \\
\text { over Time }\end{array}$ & $\begin{array}{c}\text { Gelation } \\
\text { Temperature }\end{array}$ & Biocompatibility & Encapsulation of Cells \\
\hline Agarose & $\begin{array}{c}\text { uniform gels } \\
>2.5 \% \text { protein } \\
\text { less uniform }<7.5 \% \\
\text { protein } \\
(+)\end{array}$ & $\begin{array}{l}\text { no weight } \\
\text { change } \\
\text { (+) }\end{array}$ & $\begin{array}{c}23-24{ }^{\circ} \mathrm{C} \text { with and } \\
\text { without protein } \\
\text { (+) }\end{array}$ & $\begin{array}{l}\text { non toxic } \\
\text { (+) }\end{array}$ & $\begin{array}{l}\text { possible, but with } \\
\text { inhomogeneous cell } \\
\text { distribution } \\
(+/-)\end{array}$ \\
\hline Gellan & $\begin{array}{c}\text { uniform gels } \\
>1 \% \text { protein } \\
\text { less uniform gels }<7.5 \% \\
\text { protein } \\
(+/-)\end{array}$ & $\begin{array}{l}\text { slight weight } \\
\text { change } \\
(+/ o)\end{array}$ & $\begin{array}{l}29.4{ }^{\circ} \mathrm{C} \text { without } \\
\text { protein } \\
\text { Less with protein } \\
\text { (+) }\end{array}$ & $\begin{array}{l}\text { non toxic } \\
\text { (+) }\end{array}$ & $\begin{array}{l}\text { possible with } \\
\text { homogeneous cell } \\
\text { distribution } \\
\text { (+) }\end{array}$ \\
\hline XLB & $\begin{array}{l}\text { uniform gels } \\
>1 \% \text { protein } \\
(+/-)\end{array}$ & $\begin{array}{c}\text { significant } \\
\text { weight change } \\
(-)\end{array}$ & $\begin{array}{c}56{ }^{\circ} \mathrm{C} \text { without protein } \\
\text { Less with soy protein } \\
(-)\end{array}$ & $\begin{array}{l}\text { non toxic } \\
\qquad(+)\end{array}$ & $\begin{array}{c}\text { not possible } \\
\text { (-) }\end{array}$ \\
\hline
\end{tabular}

\section{Materials and Methods}

\subsection{Hydrogel Preparation and Characterizations \\ 4.1.1. Preparation of Hydrogels}

Three polysaccharides and two protein isolates were used for preparation of hydrogels. As polysaccharides agarose (No. BP160-100, Fisher BioReagents ${ }^{\mathrm{TM}}$, Waltham, MA, USA), gellan (Kelcogel ${ }^{\circledR}$ F, CP Kelco Germany GmbH, Großenborde, Germany) and xanthan-locust bean gum blend (XLB; Kelgum ${ }^{\circledR}, \mathrm{CP}$ Kelco Germany GmbH) were mixed with different stock solutions of pea protein isolate (2\% or 15\% (w/v) PPI; Empro E 86 HV, Emsland Group, Emlichheim, Germany) and soy protein isolate (2\% or $12 \%(w / v)$ SPI; No. 905456, MP Biomedicals, Solon, OH, USA). $2 \%(w / v)$ stock solutions were used for agarose and gellan and $1 \%(w / v)$ for XLB. All three polysaccharide solutions were boiled in the microwave until solving. Then, they were mixed with a prewarmed mix $\left(37^{\circ} \mathrm{C}\right.$ for agarose and gellan; $65{ }^{\circ} \mathrm{C}$ for XLB) containing distilled $\mathrm{H}_{2} \mathrm{O}$, protein solution and $150 \mu \mathrm{L}$ DMEM high glucose (DMEMhg; No. L0101-500, Biowest, Nuaillé, France). The tested combinations and mixture ratios are shown in Table 3. After mixing, the warm gel solution was transferred into a $1 \mathrm{~mL}$ syringe (Injekt ${ }^{\circledR}-\mathrm{F}, \mathrm{B}$. Braun, Melsungen, Germany). Afterwards, $100 \mu \mathrm{L}$ was given into in-house molds ( $7 \mathrm{~mm}$ diameter, $7 \mathrm{~mm}$ height), previously put into 24 well-plates (No. 662 160, Greiner Bio-One $\mathrm{GmbH}$, Frickenhausen, Germany), and cooled down for 15 min at RT for gelation. The molds were used to ensure that the liquid polysaccharide solutions took on a reproducible, cylindrical shape during the gelation process. Gellan gels were additionally crosslinked after cooling by adding $1 \mathrm{~mL}$ DMEMhg for $15 \mathrm{~min}$. The hydrogels were evaluated macroscopically for their form stability. The gels with $0 \%, 0.5 \%$ and $1 \%$ protein concentration prepared with $2 \%$ protein solution were characterized further for their rheological, mechanical and cytotoxic properties. 
Table 3. Mixing ratios of agarose, gellan and XLB hydrogels with different protein concentrations of SPI and PPI.

\begin{tabular}{|c|c|c|c|c|c|c|c|}
\hline $\begin{array}{c}\text { Protein } \\
\text { Concentration } \\
{[\%]}\end{array}$ & $\begin{array}{c}2 \% \text { Agarose, } 2 \% \\
\text { Gellan or } 1 \% \\
\text { XLB }[\mu \mathrm{L}]\end{array}$ & $12 \%$ SPI $[\mu \mathrm{L}]$ & $\begin{array}{c}\text { Distilled } \\
\mathrm{H}_{2} \mathrm{O}[\mu \mathrm{L}]\end{array}$ & $\begin{array}{c}\text { 15\% PPI } \\
{[\mu \mathrm{L}]}\end{array}$ & $\begin{array}{c}\text { Distilled } \\
\mathrm{H}_{2} \mathrm{O}[\mu \mathrm{L}]\end{array}$ & $\begin{array}{c}2 \% \text { SPI or } \\
\text { PPI }[\mu \mathrm{L}]\end{array}$ & $\begin{array}{c}\text { Distilled } \\
\mathrm{H}_{2} \mathrm{O}[\mu \mathrm{L}]\end{array}$ \\
\hline 0 & 750 & 0 & 750 & 0 & 750 & 0 & 750 \\
\hline 0.5 & 750 & 62.5 & 687.5 & 50 & 700 & 375 & 375 \\
\hline 1 & 750 & 125 & 625 & 100 & 650 & 750 & 750 \\
\hline 2.5 & 750 & 312 & 438 & 250 & 500 & - & - \\
\hline 5 & 750 & 625 & 125 & 500 & 250 & - & - \\
\hline 6 & 750 & 750 & 0 & - & - & - & - \\
\hline 7.5 & 750 & - & - & 750 & 0 & - & - \\
\hline
\end{tabular}

\subsubsection{Rheological Properties of Hydrogels}

For all rheological measurements, a rotary oscillating rheometer (Kinexus, Malvern Panalytical, Worcestershire, UK) was used with a $1^{\circ}$ cone-plate and $60 \mathrm{~mm}$ diameter geometry. Shear viscosity was measured in a shear rate range from $0.1 \mathrm{~s}^{-1}$ to $1000 \mathrm{~s}^{-1}$ in decadal steps. Samples were heated up to a liquid state before measurement and then measured at a constant temperature (gellan and agarose: $37^{\circ} \mathrm{C}, \mathrm{XLB}: 65^{\circ} \mathrm{C}$ ).

The samples were transferred to their liquid state to measure the temperature-dependent sol-gel transitions. They were measured by oscillation at a constant frequency of $1 \mathrm{~Hz}$ and shear stress of $1 \mathrm{~Pa}$. Measurements were performed at a material-dependent temperature range (gellan: $45-15^{\circ} \mathrm{C}$, XLB: $65-30^{\circ} \mathrm{C}$ and agarose: $50-10^{\circ} \mathrm{C}$ ) with a temperature ramp of $2.5^{\circ} \mathrm{C} / \mathrm{min}$ (gellan) and $5^{\circ} \mathrm{C} / \mathrm{min}$ (XLB and agarose) at decreasing temperature.

\subsubsection{Swelling Characteristics of Hydrogels}

The weights of the hydrogels (four gels per condition; $0 \%, 0.5 \%$ and $1 \%$ pea or soy protein concentration with agarose, gellan or XLB) were measured at days $0,1,2,3$ and 7. The preparation of the gels and the weighing were carried out under sterile conditions to prevent possible contamination. The initial weight for all gels was taken 15 min after adding $1 \mathrm{~mL}$ medium (DMEMhg with 10\% fetal bovine serum, 1\% stable L-glutamine (No. P04-82050, PanBiotech, Aidenbach, Germany) and 0.2\% Primocin ${ }^{\circledR}$ (No. Ant-pm-2, InvivoGen, San Diego, CA, USA). After weighing the gels on day 3, the medium was completely replaced with fresh medium. Additionally, four gels were dried at $60{ }^{\circ} \mathrm{C}$ for seven days in an oven for dry weight determination.

The swelling ratio was calculated with the following formula:

$$
\text { Swelling ratio }[\%]=\frac{\text { initial wet weight }- \text { dry weight }}{\text { dry weight }} * 100
$$

\subsection{Cell Culture}

The murine myoblast C2C12 cell line was obtained from CLS Cell Lines Service $\mathrm{GmbH}$ (No. 400476, Eppelheim, Germany). $5 \times 10^{3} \mathrm{C} 2 \mathrm{C} 12$ cells $/ \mathrm{cm}^{2}$ were cultured in DMEM high glucose containing $10 \%$ fetal bovine serum, $1 \%$ stable L-glutamine and $0.2 \%$ Primocin (culture medium) at $37{ }^{\circ} \mathrm{C}$ with $5 \% \mathrm{CO}_{2}$. At a confluence of around $70 \%$ the cells were washed once with PBS with calcium and magnesium (PBS+; No. 17-513F, Lonza group, Basel, Switzerland) and passaged using 0.05\% trypsin (No. 25200-072, Gibco ${ }^{\mathrm{TM}}$ Thermo Fisher Scientific) diluted in $0.53 \mathrm{mM}$ EDTA solution (5 M EDTA stock solution (No. 11568896, Fisher Scientific GmbH)) diluted in PBS without calcium and magnesium (PBS-; No. BE17-516F, Lonza group). After $3-4$ min at $37{ }^{\circ} \mathrm{C}$ with $5 \% \mathrm{CO}_{2}$, the incubation was stopped by adding culture medium. A total of $1.5 \times 10^{4}$ cells were seeded per well of a 48-well plate (No. C-8219, neoLab Migge GmbH, Heidelberg, Germany). Phenol red free DMEM high glucose (No. P04-01161, PanBiotech) was used with 10\% FCS, 1\% stable L-glutamine and $0.2 \%$ Primocin for cell toxicity analysis and cell-laden gels. 


\subsection{Biocompatibility Analysis}

\subsubsection{Indirect Cell Toxicity Test}

An indirect cytotoxicity test was performed based on the ISO-10993-5. In brief, one-day and three-day leachates of 15 different biomaterial combinations $(0 \%, 0.5 \%$ and $1 \%$ pea or soy protein concentration with agarose, gellan or XLB) were produced and given to the cells. For this, $1 \mathrm{~mL}$ of each warmed biomaterial solution was poured into wells of a 24-well plate and cooled down at RT. For gellan and XLB gels, 1 mL culture medium (s. 4.2) for crosslinking was added for $15 \mathrm{~min}$. After the gelation process was completed, the gel and the medium were transferred into a $50 \mathrm{~mL}$ centrifugation tube (No. T2318, Greiner Bio-One $\mathrm{GmbH}$ ). All gels were covered with $4 \mathrm{~mL}$ culture medium in total (gel-medium ratio 1:4) and then put into an incubator with $5 \% \mathrm{CO}_{2}$ and $37{ }^{\circ} \mathrm{C}$ for 1 day or 3 days. As a negative control, a pure medium was incubated at $37{ }^{\circ} \mathrm{C}$ and $5 \% \mathrm{CO}_{2}$. For the positive control, Triton ${ }^{\mathrm{TM}}$ X-100 (No. T8787, Sigma-Aldrich, St. Louis, MI, USA) was added to a total volume of $0.1 \%$ to the previously incubated medium. After removing the cell culture medium, the leachates and controls were added to the wells (48-well plate) that were seeded with $1.5 \times 10^{4} \mathrm{C} 2 \mathrm{C} 12$ cells/well the day before. After one day of incubation at 37 ${ }^{\circ} \mathrm{C}$ and $5 \% \mathrm{CO}_{2}$, the cells were analyzed. Three wells were each analyzed with LDH and resazurin assay, and one well was used for Live/Dead-staining.

\subsubsection{Formation of Cell-Laden Gels}

The cell-laden gels were prepared similarly as described above (s. 4.1.1 Preparation of Gels). Instead of using medium alone, the same volume $(0.15 \mathrm{~mL})$ of medium was supplemented with $4.95 \times 10^{6} \mathrm{C} 2 \mathrm{C} 12$ cells, resulting in a final concentration of $3 \times 10^{6}$ cells $/ \mathrm{mL}$ gel and therefore $3 \times 10^{5}$ cells/gel. Lastly, the cell suspension was added to the polysaccharide-protein solution and heated at $37{ }^{\circ} \mathrm{C}$. Again, $100 \mu \mathrm{L}$ gels were manufactured by filling the volume into an in-house scaffold using a syringe. After cooling down at RT, the hydrogels were covered with $1 \mathrm{~mL}$ phenol red-free medium and the scaffolds were removed after a further $15 \mathrm{~min}$.

\subsubsection{LDH Assay}

To measure the released amount of lactate dehydrogenase (LDH) in cell culture supernatants, the LDH Cytotoxicity Detection Kit from Takara Bio Inc. (No. MK401, Kusatsu, Japan) was used. Briefly, duplicates of $50 \mu \mathrm{L}$ supernatant of each well were pipetted into a 96-well plate (No. 655 180, Greiner Bio-One $\mathrm{GmbH}$ ) and mixed with $50 \mu \mathrm{L}$ reaction solution (catalysator:dye solution 1:50) and incubated for $30 \mathrm{~min}$ in the dark at RT. At the end, the absorbance at $490 \mathrm{~nm}$ and a reference wavelength at $680 \mathrm{~nm}$ were measured with a SpectraMax ${ }^{\circledR}$ iD3 microplate reader (Molecular Devices LLC, San José, CA, USA).

\subsubsection{Resazurin Assay}

To determine the metabolic cell activity, a resazurin assay was performed. Before usage, the resazurin stock solution $(0.11 \mathrm{mg} / \mathrm{mL}$ resazurin (No. R7017, Sigma-Aldrich) in PBS+ was diluted with phenol red free medium (1:100). All medium was removed from the cells and replaced with $350 \mu \mathrm{L}$ of the resazurin solution per well (48-well plate). After $4 \mathrm{~h}$ of incubation at $37{ }^{\circ} \mathrm{C}$ and $5 \% \mathrm{CO}_{2}$ in an incubator, triplicates of $100 \mu \mathrm{L}$ of the metabolized resazurin solution were pipetted into a 96-well plate and measured at a SpectraMax ${ }^{\circledR}$ iD3 microplate reader (absorbance: $570 \mathrm{~nm}$, reference wavelength: $600 \mathrm{~nm}$ ).

\subsubsection{Live/Dead-Staining}

A Live/Dead ${ }^{\mathrm{TM}}$ viability/cytotoxicity kit for mammalian cells from Invitrogen by Thermo Fisher Scientific (No. L3224) was used for Live/Dead-staining. The staining solution with ethidium homodimer-1 (1:500), calcein AM (1:2000) and Hoechst 33342 (1:1000, No. 4082S, Cell Signaling Technology, Danvers, MA, USA) was prepared with PBS+. The supernatant was carefully removed from the cells/gels. Afterwards, $200 \mu \mathrm{L}$ (per 48 well) or $300 \mu \mathrm{L}$ (per 3D hydrogel) staining solution was added. After 30 min 
(2D cell cultures) or 60 min (3D hydrogels) incubation in the dark at RT, the cells were microscoped with 1:10 magnification with a fluorescence microscope (Axio Observer, Carl Zeiss AG, Jena, Germany). Different fluorescence channels were used for each staining reagent (desoxyribonucleic acid (DNA) staining with Hoechst 33342 in blue (460 nm), viable cell staining with calcein in green $(550 \mathrm{~nm})$ and dead cell staining with ethidium homodimer-1 in red $(600 \mathrm{~nm})$.

\subsection{Statistical Analysis}

The experiments were done in triplicate or quadruplicate, as mentioned. The results are presented as means \pm standard deviations. The statistical significance was determined using a two-sided $t$ student test with $p<0.05$ considered as significant.

Supplementary Materials: The following are available online at https: / www.mdpi.com/article/ 10.3390/gels8020094/s1, Figure S1: Sol-gel transition of polysaccharides (agarose, gellan and XLB) blended with $0 \%, 0.5 \%$ and $1 \%$ pea or soy protein with elastic and viscous modulus and phase angle versus temperature $(1.0 \mathrm{~Hz}$ frequency and $1 \mathrm{~Pa}$ shear stress). With gellan, a shift of the gelation point to lower temperatures of the blends compared to the native gel can be observed. Figure S2: XLB-protein blends $\left(0 \%, 0.5 \%\right.$ and $1 \%$ pea or soy protein) mixed with $3 \times 10^{5} \mathrm{C} 2 \mathrm{C} 12$ cells / gel in plate (24 well) one day after gel preparation. Scale bar: $1.55 \mathrm{~cm}$.

Author Contributions: Conceptualization, J.O.W., F.B.A. and P.J.K.; methodology, J.O.W., R.M., F.B.A., A.B. and P.J.K.; validation, J.O.W., R.M., F.B.A., A.K., S.H., A.B. and P.J.K.; formal analysis, J.O.W. and R.M.; investigation, J.O.W., R.M., F.B.A. and A.B.; resources, P.J.K.; writing-original draft preparation, J.O.W., R.M., A.K., S.H. and A.B.; writing-review and editing, F.B.A., A.K., S.H., A.B. and P.J.K.; visualization, J.O.W., R.M., A.K., S.H. and P.J.K.; supervision, A.K., S.H., A.B. and P.J.K.; project administration, P.J.K.; funding acquisition, P.J.K. All authors have read and agreed to the published version of the manuscript.

Funding: This work was funded through a research fellowship provided by New Harvest (Stafford, TX, USA) to J.O.W with the title "Serum-free bioprinted meat-Development of a serum-free co-culture medium, bioinks and a simplified CAD-model for meat printing". The Avina Foundation (Hurden, Switzerland) has supported us financially with the project "Fleischsphäroide-Grundbausteine zur nachhaltigen Herstellung von gesunden in vitro Fleischprodukten".

Institutional Review Board Statement: Not applicable.

Informed Consent Statement: Not applicable.

Data Availability Statement: Not applicable.

Acknowledgments: We thank New Harvest and the Avina Foundation for their support, which made this research possible.

Conflicts of Interest: The authors declare no conflict of interest.

\section{References}

1. Melzener, L.; Verzijden, K.E.; Buijs, A.J.; Post, M.J.; Flack, J.E. Cultured beef: From small biopsy to substantial quantity. J. Sci. Food Agric. 2021, 101, 7-14. [CrossRef] [PubMed]

2. Van Boeckel, T.P.; Pires, J.; Silvester, R.; Zhao, C.; Song, J.; Criscuolo, N.G.; Gilbert, M.; Bonhoeffer, S.; Laxminarayan, R. Global trends in antimicrobial resistance in animals in low- and middle-income countries. Science 2019, 365, eaaw1944. [CrossRef] [PubMed]

3. Wiebers, D.O.; Feigin, V.L. What the COVID-19 Crisis Is Telling Humanity. Neuroepidemiology 2020, 54, 283-286. [CrossRef] [PubMed]

4. Steinfeld, H.; Gerber, P.; Wassenaar, T.; Castel, V.; Rosales, M.; de Haan, C. Livestock's Long Shadow; FAO of the UN: Rome, Italy, 2006.

5. Chen, L.; Guttieres, D.; Koenigsberg, A.; Barone, P.W.; Sinskey, A.J.; Springs, S.L. Large-scale cultured meat production: Trends, challenges and promising biomanufacturing technologies. Biomaterials 2021, 280, 121274. [CrossRef]

6. Bonny, S.P.F.; Gardner, G.E.; Pethick, D.W.; Hocquette, J.-F. What is artificial meat and what does it mean for the future of the meat industry? J. Integr. Agric. 2015, 14, 255-263. [CrossRef]

7. Seah, J.S.H.; Singh, S.; Tan, L.P.; Choudhury, D. Scaffolds for the manufacture of cultured meat. Crit. Rev. Biotechnol. 2021, 42(2), 311-323. [CrossRef] 
8. Furuhashi, M.; Morimoto, Y.; Shima, A.; Nakamura, F.; Ishikawa, H.; Takeuchi, S. Formation of contractile 3D bovine muscle tissue for construction of millimetre-thick cultured steak. NPJ Sci. Food 2021, 5, 6. [CrossRef]

9. Baker, B.M.; Chen, C.S. Deconstructing the third dimension: How 3D culture microenvironments alter cellular cues. J. Cell Sci. 2012, 125, 3015-3024. [CrossRef]

10. Bomkamp, C.; Skaalure, S.C.; Fernando, G.F.; Ben-Arye, T.; Swartz, E.W.; Specht, E.A. Scaffolding Biomaterials for 3D Cultivated Meat: Prospects and Challenges. Adv. Sci. 2021, 9, e2102908. [CrossRef]

11. O'Neill, E.N.; Cosenza, Z.A.; Baar, K.; Block, D.E. Considerations for the development of cost-effective cell culture media for cultivated meat production. Compr. Rev. Food Sci. Food Saf. 2021, 20, 686-709. [CrossRef]

12. Bekker, G.A.; Tobi, H.; Fischer, A.R.H. Meet meat: An explorative study on meat and cultured meat as seen by Chinese, Ethiopians and Dutch. Appetite 2017, 114, 82-92. [CrossRef] [PubMed]

13. Verbruggen, S.; Luining, D.; van Essen, A.; Post, M.J. Bovine myoblast cell production in a microcarriers-based system. Cytotechnology 2018, 70, 503-512. [CrossRef] [PubMed]

14. Wu, C.-Y.; Stoecklein, D.; Kommajosula, A.; Lin, J.; Owsley, K.; Ganapathysubramanian, B.; Di Carlo, D. Shaped 3D microcarriers for adherent cell culture and analysis. Microsyst. Nanoeng. 2018, 4, 21. [CrossRef]

15. Derakhti, S.; Safiabadi-Tali, S.H.; Amoabediny, G.; Sheikhpour, M. Attachment and detachment strategies in microcarrier-based cell culture technology: A comprehensive review. Mater. Sci. Eng. C Mater. Biol. Appl. 2019, 103, 109782. [CrossRef]

16. Nie, M.; Shima, A.; Fukushima, K.; Morimoto, Y.; Takeuchi, S. A Cylindrical Molding Method for the Biofabrication of PlaneShaped Skeletal Muscle Tissue. Micromachines 2021, 12, 1411. [CrossRef]

17. Osidak, E.O.; Karalkin, P.A.; Osidak, M.S.; Parfenov, V.A.; Sivogrivov, D.E.; Pereira, F.D.A.S.; Gryadunova, A.A.; Koudan, E.V.; Khesuani, Y.D.; Kasyanov, V.A.; et al. Viscoll collagen solution as a novel bioink for direct 3D bioprinting. J. Mater. Sci. Mater. Med. 2019, 30, 31. [CrossRef] [PubMed]

18. Kim, J.H.; Kim, I.; Seol, Y.-J.; Ko, I.K.; Yoo, J.J.; Atala, A.; Lee, S.J. Neural cell integration into 3D bioprinted skeletal muscle constructs accelerates restoration of muscle function. Nat. Commun. 2020, 11, 1025. [CrossRef] [PubMed]

19. Enrione, J.; Blaker, J.J.; Brown, D.I.; Weinstein-Oppenheimer, C.R.; Pepczynska, M.; Olguín, Y.; Sánchez, E.; Acevedo, C.A. Edible Scaffolds Based on Non-Mammalian Biopolymers for Myoblast Growth. Materials 2017, 10, 1404. [CrossRef]

20. Hume, S.L.; Hoyt, S.M.; Walker, J.S.; Sridhar, B.V.; Ashley, J.F.; Bowman, C.N.; Bryant, S.J. Alignment of multi-layered muscle cells within three-dimensional hydrogel macrochannels. Acta Biomater. 2012, 8, 2193-2202. [CrossRef]

21. Ben-Arye, T.; Shandalov, Y.; Ben-Shaul, S.; Landau, S.; Zagury, Y.; Ianovici, I.; Lavon, N.; Levenberg, S. Textured soy protein scaffolds enable the generation of three-dimensional bovine skeletal muscle tissue for cell-based meat. Nat. Food 2020, 1, 210-220. [CrossRef]

22. Bačáková, L.; Novotná, K.; Pařízek, M. Polysaccharides as cell carriers for tissue engineering: The use of cellulose in vascular wall reconstruction. Physiol. Res. 2014, 63, S29-S47. [CrossRef]

23. Lee, W.-K.; Lim, Y.-Y.; Leow, A.T.-C.; Namasivayam, P.; Ong Abdullah, J.; Ho, C.-L. Biosynthesis of agar in red seaweeds: A review. Carbohydr. Polym. 2017, 164, 23-30. [CrossRef]

24. Cidonio, G.; Cooke, M.; Glinka, M.; Dawson, J.I.; Grover, L.; Oreffo, R.O.C. Printing bone in a gel: Using nanocomposite bioink to print functionalised bone scaffolds. Mater. Today Bio. 2019, 4, 100028. [CrossRef]

25. Tanaka, N.; Moriguchi, H.; Sato, A.; Kawai, T.; Shimba, K.; Jimbo, Y.; Tanaka, Y. Microcasting with agarose gel via degassed polydimethylsiloxane molds for repellency-guided cell patterning. RSC Adv. 2016, 6, 54754-54762. [CrossRef]

26. Del Garcia Cruz, M.R.; Postma, A.; Frith, J.E.; Meagher, L. Printability and bio-functionality of a shear thinning methacrylated xanthan-Gelatin composite bioink. Biofabrication 2021, 13, 035023. [CrossRef]

27. Jan, A.; Delcour, K.P. Fibre-Rich and Wholegrain Foods: Improving Quality; Woodhead: Sawston, UK, 2013 ; ISBN 9780857090386.

28. Gorissen, S.H.M.; Crombag, J.J.R.; Senden, J.M.G.; Waterval, W.A.H.; Bierau, J.; Verdijk, L.B.; van Loon, L.J.C. Protein content and amino acid composition of commercially available plant-based protein isolates. Amino Acids 2018, 50, 1685-1695. [CrossRef]

29. Czaja-Bulsa, G.; Bulsa, M. What Do We Know Now about IgE-Mediated Wheat Allergy in Children? Nutrients 2017, 9, 35. [CrossRef]

30. Palmieri, B.; Vadala', M.; Laurino, C. Gluten-free diet in non-celiac patients: Beliefs, truths, advantages and disadvantages. Minerva Gastroenterol. Dietol. 2019, 65, 153-162. [CrossRef]

31. Armisén, R.; Galatas, F.; Hispanagar, S.A. Handbook of Hydrocolloids, 2nd ed.; CRC: Boca Raton, FL, USA; Woodhead: Oxford, UK, 2009; ISBN 978-1-84569-414-2.

32. Mortensen, A.; Aguilar, F.; Crebelli, R.; Di Domenico, A.; Frutos, M.J.; Galtier, P.; Gott, D.; Gundert-Remy, U.; Lambré, C.; Leblanc, J.-C.; et al. Re-evaluation of agar (E 406) as a food additive. EFS2 2016, 14, e04645. [CrossRef]

33. Santos, R.; Melo, R.A. Global shortage of technical agars: Back to basics (resource management). J. Appl. Phycol. 2018, 30, 2463-2473. [CrossRef]

34. Vijay Anand, K.G.; Eswaran, K.; Ghosh, A. Life cycle impact assessment of a seaweed product obtained from Gracilaria edulis-A potent plant biostimulant. J. Clean. Prod. 2018, 170, 1621-1627. [CrossRef]

35. Jenzer, H.; Müller, S.; Rotunno, F.; Maurer, N.D.; Rufener, A.; Marty, I.; Martins, S.; Sadeghi, L. PP-007 Evaluation of amylaseresistant gellan GUM (E418) as a rheology and texture modifier for oral preparations. Eur. J. Hosp. Pharm. 2016, 23, A197. [CrossRef] 
36. Younes, M.; Aggett, P.; Aguilar, F.; Crebelli, R.; Filipic, M.; Frutos, M.J.; Galtier, P.; Gott, D.; Gundert-Remy, U.; Kuhnle, G.G.; et al. Re-evaluation of gellan gum (E 418) as food additive. EFSA J. 2018, 16, e05296. [CrossRef]

37. Zia, K.M.; Tabasum, S.; Khan, M.F.; Akram, N.; Akhter, N.; Noreen, A.; Zuber, M. Recent trends on gellan gum blends with natural and synthetic polymers: A review. Int. J. Biol. Macromol. 2018, 109, 1068-1087. [CrossRef]

38. Li, A.; Hu, T.; Luo, H.; Alam, N.-U.; Xin, J.; Li, H.; Lin, Y.; Huang, J.; Huang, K.; Meng, Y.; et al. A Carotenoid- and Poly- $\beta$ Hydroxybutyrate-Free Mutant Strain of Sphingomonas elodea ATCC 31461 for the Commercial Production of Gellan. $m S p h e r e$ 2019, 4, e00668-19. [CrossRef]

39. Raghunandan, K.; Kumar, A.; Kumar, S.; Permaul, K.; Singh, S. Production of gellan gum, an exopolysaccharide, from biodieselderived waste glycerol by Sphingomonas spp. 3 Biotech 2018, 8, 71. [CrossRef]

40. West, T.P. Synthesis of the Microbial Polysaccharide Gellan from Dairy and Plant-Based Processing Coproducts. Polysaccharides 2021, 2, 234-244. [CrossRef]

41. Directorate General for Agriculture and Rural Development. Expert Group for Technical Advice on Organic Production: Final Report On Food (III); European Commission: Brussels, Belgium, 2014.

42. Industrial Microbiology; Wilson, D.B.; Sahm, H.; Stahmann, K.-P.; Koffas, M. (Eds.) Wiley-VCH: Weinheim, Germany, 2020; ISBN 978-3-527-34035-4.

43. Mortensen, A.; Aguilar, F.; Crebelli, R.; Di Domenico, A.; Frutos, M.J.; Galtier, P.; Gott, D.; Gundert-Remy, U.; Lambré, C.; Leblanc, J.-C.; et al. Re-evaluation of xanthan gum (E 415) as a food additive. EFSA J. 2017, 15, e04909. [CrossRef]

44. Kumar, A.; Rao, K.M.; Han, S.S. Application of xanthan gum as polysaccharide in tissue engineering: A review. Carbohydr. Polym. 2018, 180, 128-144. [CrossRef]

45. Li, P.; Li, T.; Zeng, Y.; Li, X.; Jiang, X.; Wang, Y.; Xie, T.; Zhang, Y. Biosynthesis of xanthan gum by Xanthomonas campestris LRELP-1 using kitchen waste as the sole substrate. Carbohydr. Polym. 2016, 151, 684-691. [CrossRef]

46. Chang, I.; Im, J.; Cho, G.-C. Introduction of Microbial Biopolymers in Soil Treatment for Future Environmentally-Friendly and Sustainable Geotechnical Engineering. Sustainability 2016, 8, 251. [CrossRef]

47. Latifi, N.; Horpibulsuk, S.; Meehan, C.L.; Majid, M.A.; Rashid, A.S.A. Xanthan gum biopolymer: An eco-friendly additive for stabilization of tropical organic peat. Environ. Earth Sci. 2016, 75, 825. [CrossRef]

48. Maiti, S.; Dey, P.; Banik, A.; Sa, B.; Ray, S.; Kaity, S. Tailoring of locust bean gum and development of hydrogel beads for controlled oral delivery of glipizide. Drug Deliv. 2010, 17, 288-300. [CrossRef]

49. Liu, F.; McConnell, E.L.; Pygall, S. Update on Polymers for Oral Drug Delivery; iSmithers: Shawsbury, UK, 2011; ISBN 978-1847355379.

50. Mortensen, A.; Aguilar, F.; Crebelli, R.; Di Domenico, A.; Frutos, M.J.; Galtier, P.; Gott, D.; Gundert-Remy, U.; Lambré, C.; Leblanc, J.-C.; et al. Re-evaluation of locust bean gum (E 410) as a food additive. EFS2 2017, 15, e04646. [CrossRef]

51. Prajapati, V.D.; Jani, G.K.; Moradiya, N.G.; Randeria, N.P.; Nagar, B.J. Locust bean gum: A versatile biopolymer. Carbohydr. Polym. 2013, 94, 814-821. [CrossRef]

52. Cerqueira, M.A.P.R.; Pereira, R.N.C.; Da Ramos, O.L.S.; Teixeira, J.A.C.; Vicente, A.A. (Eds.) Edible Food Packaging: Materials and Processing Technologies; CRC Press: Boca Raton, FL, USA, 2016; ISBN 9781482234169.

53. Boublenza, I.; Boublenza, I.; Boublenza, A.; Madji, S.; Fabiano-Tixier, A.-S.; Chemat, F. Carob as Source for Sustainable Ingredients and Products. In Plant Based "Green Chemistry 2.0"; Li, Y., Chemat, F., Eds.; Springer: Singapore, 2019; pp. 257-275. ISBN 978-981-13-3809-0.

54. Issaoui, M.; Flamini, G.; Delgado, A. Sustainability Opportunities for Mediterranean Food Products through New Formulations Based on Carob Flour (Ceratonia siliqua L.). Sustainability 2021, 13, 8026. [CrossRef]

55. Roland, W.S.U.; Pouvreau, L.; Curran, J.; van de Velde, F.; de Kok, P.M.T. Flavor Aspects of Pulse Ingredients. Cereal Chem. J. 2017, 94, 58-65. [CrossRef]

56. Gläser, P.; Dawid, C.; Meister, S.; Bader-Mittermaier, S.; Schott, M.; Eisner, P.; Hofmann, T. Molecularization of Bitter Off-Taste Compounds in Pea-Protein Isolates (Pisum sativum L.). J. Agric. Food Chem. 2020, 68, 10374-10387. [CrossRef]

57. U.S. Food and Drug Administration. GRAS Notice 788 for Pea Protein Concentrate; Recently Published GRAS Notices and FDA Letters; U.S. Food and Drug Administration: Silver Spring, MD, USA, 2018.

58. Taylor, S.L.; Marsh, J.T.; Koppelman, S.J.; Kabourek, J.L.; Johnson, P.E.; Baumert, J.L. A perspective on pea allergy and pea allergens. Trends Food Sci. Technol. 2021, 116, 186-198. [CrossRef]

59. Barac, M.; Pesic, M.; Stanojevic, S.; Kostic, A.; Cabrilo, S. Techno-functional properties of pea (Pisum sativum) protein isolates: A review. Acta Period. Techol. 2015, 46, 1-18. [CrossRef]

60. U.S. Food and Drug Administration. GRAS Notice 851 Pea Protein; No. 851; Recently Published GRAS Notices and FDA Letters; U.S. Food and Drug Administration: Silver Spring, MD, USA, 2020.

61. Markets and Markets. Pea Protein Market by Type (Isolates, Concentrates, and Textured), Form (Dry and Wet): Source (Yellow Split Peas, Lentils, and Chickpeas), Application, and Region (North America, Europe, Asia Pacific, South America, and Rest of the World)—Global Forecast to 2025; No. 5003970; Research and Markets: Rockville, MD, USA, 2020.

62. Berardy, A.; Johnston, C.S.; Plukis, A.; Vizcaino, M.; Wharton, C. Integrating Protein Quality and Quantity with Environmental Impacts in Life Cycle Assessment. Sustainability 2019, 11, 2747. [CrossRef]

63. Final Rule Department of Health and Human Services Food and Drug Administration. Federal Register Volume 64 , Issue 206 (October 26, 1999): Food Labeling: Health Claims; Soy Protein and Coronary Heart Disease; Regulatory Information 64 FR 57700 , Docket No. 98P-0683; U.S. Food and Drug Administration: Silver Spring, MD, USA, 1999. 
64. Cordle, C.T. Soy protein allergy: Incidence and relative severity. J. Nutr. 2004, 134, 1213S-1219S. [CrossRef]

65. Singh, P.; Kumar, R.; Sabapathy, S.N.; Bawa, A.S. Functional and Edible Uses of Soy Protein Products. Comp. Rev. Food Sci. Food Saf. 2008, 7, 14-28. [CrossRef]

66. EFSA. Scientific Opinion on the substantiation of a health claim related to soy protein and reduction of blood cholesterol concentrations pursuant to Article 14 of the Regulation (EC) No 1924/2006. EFS2 2010, 8, 1688. [CrossRef]

67. Sui, X.; Zhang, T.; Jiang, L. Soy Protein: Molecular Structure Revisited and Recent Advances in Processing Technologies. Annu. Rev. Food Sci. Technol. 2021, 12, 119-147. [CrossRef]

68. Andrew, B.; Christine, C.; Thomas, S. Life Cycle Assessment of Soy Protein Isolate. In Proceedings of the International Symposium on Sustainable Systems and Technologies, Phoenix, AZ, USA, 16-18 May 2015.

69. Reijnders, L.; Soret, S. Quantification of the environmental impact of different dietary protein choices. Am. J. Clin. Nutr. 2003, 78, 664S-668S. [CrossRef]

70. Casas, J.A.; Garca-Ochoa, F. Viscosity of solutions of xanthan/locust bean gum mixtures. J. Sci. Food Agric. 1999, 79, 25-31. [CrossRef]

71. Zarrintaj, P.; Manouchehri, S.; Ahmadi, Z.; Saeb, M.R.; Urbanska, A.M.; Kaplan, D.L.; Mozafari, M. Agarose-based biomaterials for tissue engineering. Carbohydr. Polym. 2018, 187, 66-84. [CrossRef]

72. Renou, F.; Petibon, O.; Malhiac, C.; Grisel, M. Effect of xanthan structure on its interaction with locust bean gum: Toward prediction of rheological properties. Food Hydrocoll. 2013, 32, 331-340. [CrossRef]

73. Higiro, J.; Herald, T.J.; Alavi, S.; Bean, S. Rheological study of xanthan and locust bean gum interaction in dilute solution: Effect of salt. Food Res. Int. 2007, 40, 435-447. [CrossRef]

74. Ghebremedhin, M.; Schreiber, C.; Zielbauer, B.; Dietz, N.; Vilgis, T.A. Interaction of xanthan gums with galacto- and glucomannans. Part II: Heat induced synergistic gelation mechanism and their interaction with salt. J. Phys. Mater. 2021, 3, 34014. [CrossRef]

75. Petri, D.F.S. Xanthan gum: A versatile biopolymer for biomedical and technological applications. J. Appl. Polym. Sci. 2015, 132, 1-13. [CrossRef]

76. Chien, K.B.; Chung, E.J.; Shah, R.N. Investigation of soy protein hydrogels for biomedical applications: Materials characterization, drug release, and biocompatibility. J. Biomater. Appl. 2014, 28, 1085-1096. [CrossRef]

77. Tansaz, S.; Singh, R.; Cicha, I.; Boccaccini, A.R. Soy Protein-Based Composite Hydrogels: Physico-Chemical Characterization and In Vitro Cytocompatibility. Polymers 2018, 10, 1159. [CrossRef]

78. Nordqvist, D.; Vilgis, T.A. Rheological Study of the Gelation Process of Agarose-Based Solutions. Food Biophys. 2011, 6, 450-460. [CrossRef]

79. Morris, E.R.; Nishinari, K.; Rinaudo, M. Gelation of gellan-A review. Food Hydrocoll. 2012, 28, 373-411. [CrossRef]

80. Hege, J.; Palberg, T.; Vilgis, T.A. Interactions of different hydrocolloids with milk proteins. J. Phys. Mater. 2020, 3, 44003. [CrossRef]

81. Duarte Campos, D.F.; Blaeser, A. 3D-Bioprinting. In Basic Concepts on 3D Cell Culture; Kasper, C., Egger, D., Lavrentieva, A., Eds.; Springer International Publishing: Cham, Switzerland, 2021; pp. 201-232. ISBN 978-3-030-66748-1.

82. Yue, Y.; Pang, S.; Li, N.; Tong, L.; Wang, L.; Fan, B.; Li, C.; Wang, F.; Liu, L. Interactions between Pea Protein Isolate and Carboxymethylcellulose in Neutral and Acid Aqueous Systems. Foods 2021, 10, 1560. [CrossRef]

83. Albano, K.M.; Cavallieri, Â.L.F.; Nicoletti, V.R. Electrostatic interaction between proteins and polysaccharides: Physicochemical aspects and applications in emulsion stabilization. Food Rev. Int. 2019, 35, 54-89. [CrossRef]

84. Braudo, E.E.; Plashchina, I.G.; Schwenke, K.D. Plant protein interactions with polysaccharides and their influence on legume protein functionality A Review. Nahrung 2001, 45, 382. [CrossRef]

85. Le, X.T.; Rioux, L.-E.; Turgeon, S.L. Formation and functional properties of protein-polysaccharide electrostatic hydrogels in comparison to protein or polysaccharide hydrogels. Adv. Colloid Interface Sci. 2017, 239, 127-135. [CrossRef]

86. Jones, O.G.; McClements, D.J. Recent progress in biopolymer nanoparticle and microparticle formation by heat-treating electrostatic protein-polysaccharide complexes. Adv. Colloid Interface Sci. 2011, 167, 49-62. [CrossRef]

87. Roterman, I.; Banach, M.; Kalinowska, B.; Konieczny, L. Influence of the Aqueous Environment on Protein Structure-A Plausible Hypothesis Concerning the Mechanism of Amyloidogenesis. Entropy 2016, 18, 351. [CrossRef]

88. Guzzo, A.V. The Influence of Amino Acid Sequence on Protein Structure. Biophys. J. 1965, 5, 809-822. [CrossRef]

89. Huang, X.; Li, J.; Luo, J.; Gao, Q.; Mao, A.; Li, J. Research progress on double-network hydrogels. Mater. Today Commun. 2021, 29, 102757. [CrossRef]

90. Blaeser, A.; Duarte Campos, D.F.; Puster, U.; Richtering, W.; Stevens, M.M.; Fischer, H. Controlling Shear Stress in 3D Bioprinting is a Key Factor to Balance Printing Resolution and Stem Cell Integrity. Adv. Healthc. Mater. 2016, 5, 326-333. [CrossRef]

91. Abchiche, H.; Mellal, M.; Sahraoui, N.; Bertouche, S.; Tebachi, L.; Mameri, A. The Study of The Effect of Concentration of The Agar-Agar Solution on The Rheological and Thermo Rheological Behavior. EJEST 2020, 3, 105-113. [CrossRef]

92. Vigata, M.; Meinert, C.; Hutmacher, D.W.; Bock, N. Hydrogels as Drug Delivery Systems: A Review of Current Characterization and Evaluation Techniques. Pharmaceutics 2020, 12, 1188. [CrossRef]

93. Singh, Y.P.; Bhardwaj, N.; Mandal, B.B. Potential of Agarose/Silk Fibroin Blended Hydrogel for in Vitro Cartilage Tissue Engineering. ACS Appl. Mater. Interfaces 2016, 8, 21236-21249. [CrossRef]

94. De Silva, D.A.; Poole-Warren, L.A.; Martens, P.J.; Panhuis, M.I.H. Mechanical characteristics of swollen gellan gum hydrogels. J. Appl. Polym. Sci. 2013, 130, 3374-3383. [CrossRef]

95. Hayes, M. Measuring Protein Content in Food: An Overview of Methods. Foods 2020, 9, 1340. [CrossRef] 
96. Wang, Z.; Wang, Z.; Lu, W.W.; Zhen, W.; Yang, D.; Peng, S. Novel biomaterial strategies for controlled growth factor delivery for biomedical applications. NPG Asia Mater. 2017, 9, e435. [CrossRef]

97. Northoff, H.; Flegel, W.A. Fetal Calf Serum. In Encyclopedia of Immunology; Elsevier: Amsterdam, The Netherlands, 1998; pp 896-897. ISBN 9780122267659.

98. Kolkmann, A.M.; Post, M.J.; Rutjens, M.A.M.; van Essen, A.L.M.; Moutsatsou, P. Serum-free media for the growth of primary bovine myoblasts. Cytotechnology 2020, 72(1), 111-120. [CrossRef]

99. Zhang, G.; Zhao, X.; Li, X.; Du, G.; Zhou, J.; Chen, J. Challenges and possibilities for bio-manufacturing cultured meat. Trends Food Sci. Technol. 2020, 97, 443-450. [CrossRef]

100. Messmer, T.; Klevernic, I.; Furquim, C.; Ovchinnikova, E.; Dogan, A.; Cruz, H.; Post, M.J.; Flack, J.E. A serum-free media formulation for cultured meat production supports bovine satellite cell differentiation in the absence of serum starvation. Nat. Food 2022, 3, 74-85. [CrossRef]

101. Volz, A.-C.; Kluger, P.J. Completely serum-free and chemically defined adipocyte development and maintenance. Cytotherapy 2018, 20, 576-588. [CrossRef]

102. Leber, B.; Mayrhauser, U.; Leopold, B.; Koestenbauer, S.; Tscheliessnigg, K.; Stadlbauer, V.; Stiegler, P. Impact of temperature on cell death in a cell-culture model of hepatocellular carcinoma. Anticancer Res. 2012, 32, 915-921.

103. Dani, S.; Ahlfeld, T.; Albrecht, F.; Duin, S.; Kluger, P.; Lode, A.; Gelinsky, M. Homogeneous and Reproducible Mixing of Highly Viscous Biomaterial Inks and Cell Suspensions to Create Bioinks. Gels 2021, 7, 227. [CrossRef]

104. Geckil, H.; Xu, F.; Zhang, X.; Moon, S.; Demirci, U. Engineering hydrogels as extracellular matrix mimics. Nanomedicine 2010, 5 , 469-484. [CrossRef]

105. Su, Y.; Chu, B.; Gao, Y.; Wu, C.; Zhang, L.; Chen, P.; Wang, X.; Tang, S. Modification of agarose with carboxylation and grafting dopamine for promotion of its cell-adhesiveness. Carbohydr. Polym. 2013, 92, 2245-2251. [CrossRef]

106. Bacelar, A.H.; Silva-Correia, J.; Oliveira, J.M.; Reis, R.L. Recent progress in gellan gum hydrogels provided by functionalization strategies. J. Mater. Chem. B 2016, 4, 6164-6174. [CrossRef]

107. Bektas, E.I.; Gurel Pekozer, G.; Kök, F.N.; Torun Kose, G. Evaluation of natural gum-based cryogels for soft tissue engineering Carbohydr. Polym. 2021, 271, 118407. [CrossRef]

108. Mohammadinejad, R.; Maleki, H.; Larrañeta, E.; Fajardo, A.R.; Nik, A.B.; Shavandi, A.; Sheikhi, A.; Ghorbanpour, M.; Farokhi, M.; Govindh, P.; et al. Status and future scope of plant-based green hydrogels in biomedical engineering. Appl. Mater. Today 2019, 16, 213-246. [CrossRef]

109. Liu, C.; Chen, Y.; Wang, X.; Huang, J.; Chang, P.R.; Anderson, D.P. Improvement in physical properties and cytocompatibility of zein by incorporation of pea protein isolate. J. Mater. Sci. 2010, 45, 6775-6785. [CrossRef]

110. Ferris, C.J.; Panhuis, M.I.H. Conducting bio-materials based on gellan gum hydrogels. Soft Matter. 2009, 5, 3430. [CrossRef]

111. Hara, S.; Aoki, S.; Nagata, M.; Shirasuna, K.; Noguchi, T.; Iwata, H. Xanthan gum and locust bean gum substrate improves bovine embryo development. Reprod. Domest. Anim. 2020, 55, 1124-1131. [CrossRef]

112. Chen, H.; Zhong, J.; Wang, J.; Huang, R.; Qiao, X.; Wang, H.; Tan, Z. Enhanced growth and differentiation of myoblast cells grown on E-jet 3D printed platforms. Int. J. Nanomed. 2019, 14, 937-950. [CrossRef] 